\title{
Influence of Administration Route and Dose on Biodistribution Profile and Effects of PEG-PLA Nanoparticles in Mice
}

\author{
Sangeetha Aula ${ }^{1,2}$, Samyuktha Lakkireddy ${ }^{1,2}$, Atya Kapley ${ }^{1,3}$, Rakesh Kumar Sharma ${ }^{4}$, \\ Shantveer G Uppin ${ }^{5}$ and Kaiser Jamil ${ }^{1 *}$ \\ ${ }^{1}$ Centre for Biotechnology and Bioinformatics, Jawaharlal Nehru Institute of Advanced Studies \\ (JNIAS), Secunderabad, Telangana, India \\ 2 Department of Biotechnology, Jawaharlal Nehru Technological University Anantapur (JNTUA), \\ Ananthapuramu, Andhra Pradesh, India \\ ${ }^{3}$ Environmental Genomics Division, Council of Scientific and Industrial Research-National \\ Environmental Engineering Research Institute (CSIR-NEERI), Nagpur, Maharashtra, India \\ ${ }^{4}$ Saveetha Institute of Medical and Technical Sciences (SIMATS), 162, Poonamallee High Road, \\ Chennai, Tamilnadu, India \\ ${ }^{5}$ Department of Pathology, Nizam's Institute of Medical Sciences (NIMS), Hyderabad, Telangana, \\ India
}

\section{ARTICLE INFO}

Keywords:
PEG-PLA Nanoparticles
Biodistribution
Blood Kinetics
Oxidative Stress
Hemocompatibility
Genotoxicity
Histopathology

\begin{abstract}
Polyethylene glycol-polylactic acid nanoparticles (PEG-PLA NPs) represent a new generation of parenteral therapeutics systems. Following administration, these NPs possess the potential to interact with biological machinery. Therefore, it is essential to get a systematic understanding of the biological fate of these NPs to evaluate their safety. In the present study, two doses (20 and $40 \mathrm{mg} / \mathrm{kg}$ ) of technetium- $99 \mathrm{~m}$ labeled PEG-PLA NPs were administered intravenous (i.v.) and oral into mice and the distribution was assessed at 1, 2, 4 and $24 \mathrm{~h}$ post administration. Biodistribution and blood kinetic profiles revealed the extended systemic circulation of the NPs. Dose-dependent presence of NPs $(p<0.05)$ was detected in the blood, liver, lung, spleen, and kidney of i.v. injected mice, and also in the blood, lung, spleen, stomach, and intestine of oral administered mice. The consequences of NP interaction with the biological components were studied by measurement of hematology, oxidative stress, genotoxic and histological parameters. Significantly increased levels of oxidative stress markers such as glutathione were observed in the liver, and spleen of i.v. injected mice and liver, stomach, and intestine of orally treated mice. Decreased lipid peroxidation levels $(p<0.05)$ were observed in the liver of orally treated mice versus untreated mice. Even though PEG-PLA NPs have been shown to induce oxidative DNA damage, interestingly no histological lesions were observed in selected organs except lung of i.v. treated mice, which showed moderate vascular congestion. Such insights on in vivo distribution and understanding of nano-bio interactions at molecular and genetic levels are considered fundamental for the designing of safer nanoparticles for biomedical applications.
\end{abstract}

\section{Introduction}

Design and exploration of a variety of engineered nanoparticles (NPs) such as polymers, inorganic materials, hybrid composites etc. for diverse biomedical applications such as drug carriers/therapeutic agents in disease therapy, magnetic resonance contrasts in diagnosis/imaging etc. has improved considerably in recent years (Raffaele Conte et al., 2018). Currently,

\footnotetext{
* Corresponding Author E-Mail Address: kaiserjamilgene@gmail.com
} 
polymeric NPs are receiving greater attention in the field of tissue engineering in addition to the aforementioned applications. These NPs were found to improve the regenerative capabilities of biomaterials and thus have been explored as promising candidates in tissue engineering (Pourhojat et al., 2018 \& Teleanu et., al 2019). This is supported by the extensive application of FDA-approved polymers such as polylactic acid (PLA) and its co-polymers in skin tissue engineering (Saini et al., 2016). PLA has become "material of choice" in biomedical field due to its biocompatibility, biodegradability, processability etc. Blending PLA with other polymers such as polyethylene glycol (PEG) presents a convenient choice to improve its properties or create novel properties for target applications (Aula et al., 2015) wherein PEGylation enhances the stability of NP systems (Li et al., 2019). Among polymeric nanotechnologies, PEG-PLA NP systems have been emerging as a revolutionary carrier establishment of drug delivery, therapy and diagnosis. In these NPs, generally PLA forms the core and PEG forms the corona, thereby protecting the NPs from aggregation. These NPs can be used both by oral and by intravenous (i.v.) routes for drug delivery. The key function of PEG in offering protection to the surface of PEG-PLA NPs is supported by an earlier study wherein oral administration of these NPs in rats led to only 3\% degradation (assessed by formation of lactate) compared to 9\% degradation with PLA NPs (Tobio et al., 2000). Moreover, i.v. injected PEG-PLA NPs exhibit prolonged systemic circulation and thereby enhance the half-life of the encapsulated therapeutic agents and their distribution to tissues possessing leaky endothelium through enhanced permeability and retention (EPR) effect (Bazile et al., 1995). The significant application of PEG-PLA NPs as carrier systems in enhancing the delivery of active pharmaceutical ingredients to achieve improved therapeutic response is also evident from several studies (Yu et al., 2010 \& Li et al., 2014). Further support is provided by the successful use of PEGylated long circulating nano-objects for therapeutic applications. These include the commercialization of (i) PEGylated liposomal doxorubicin (Doxil ${ }^{\circledR} /$ Caelyx $^{\circledR}$ ), (ii) PEG-PLA micellar formulation, Genexol-PM (an anticancer agent paclitaxel loaded micelles) for the treatment of metastatic or recurrent breast cancer, and locally advanced or metastatic non-small cell lung cancer as first-line therapy (Reddy \& Bazile., 2014b), while the docetaxel-loaded PEG-PLA NPs formulation, BIND014, intended for treatment of metastatic castration-resistant prostate cancer (mCRPC) is currently in clinical testing (Autio et al., 2018). The efficacy of methoxy PEG-PLA NPs (mPEG-PLA NPs) in safe and sustained release of recombinant human growth hormone (rhGH) has been demonstrated in vitro (Ghasemi et al., 2019). The potential of ((S)-2-(3-((S)-5-amino-1-carboxypentyl) ureido) pentanedioic acid (ACUPA)-conjugated PEG-PLA nanosystem containing galbanic acid and docetaxel in successfully targeting prostate-specific membrane antigen (PSMA) in prostate cancer cell lines has paved the way for its use as an effective carrier for various cancers with limited therapeutic efficacy (Afsharzadeh et al., 2020).

Even though PEG-PLA NP systems possess several advantages for biomedical applications, some adverse effects such as hypersensitivity, neuropathy, neutropenia, fatigue, anemia, thrombocytopenia etc. are associated with their use (Reddy \& Bazile., 2014b). The induction of "Accelerated Blood Clearance (ABC)" phenomenon for PEGylated polymeric NPs has been reported, however, information on other key factors such as influence of administration route, dose, consequences of NPs interaction with the biological milieu etc. connected with their applications are limited and need to be investigated when a new PEGylated NP system is developed (Reddy et al., 2012). Hence, it is essential to attain a thorough knowledge on the biodistribution of PEG-PLA NPs, their interaction with the biological components, the resulting implications at the molecular and genetic levels to assess the NPs safety levels for the intended application. 
In the present study, we have assessed the biodistribution pattern using two doses of technetium-99m $\left({ }^{99 \mathrm{~m}} \mathrm{Tc}\right)$ labeled PEG-PLA NPs $(20$ and $40 \mathrm{mg} / \mathrm{kg}$ body weight) in mice, following i.v. and oral routes of administration. Additionally, the effect of dose and administration route on the toxicity factors such as, hematological, biochemical and histological parameters were also assessed. The cellular and tissue responses in terms of oxidative stress, DNA damage, in the organs experiencing high distribution of NPs based on the biodistribution data were also investigated.

\section{Materials and Methods}

\subsection{Materials}

Monomethoxypoly (ethylene glycol)-b-poly (D,L-lactic acid) (mPEG-PLA) copolymer was a kind gift from Sanofi R\&D, France (number average molecular weights $\left[\mathrm{M}_{\mathrm{n}}\right]$ of PEG and PLA are $5000 \mathrm{~g} / \mathrm{mol}$ and 35,200 g/mol, respectively). Normal melting agarose (NMA), Ethylenediaminetetraacetic acid (EDTA) disodium salt, sodium lauroyl sarcosinate, cysteine, diethylene triamine pentaacetic acid (DTPA) and stannous chloride dihydrate $\left(\mathrm{SnCl}_{2} 2 \mathrm{H}_{2} \mathrm{O}\right)$ were procured from Sigma Aldrich Corporation (St. Louis, MO 63103, USA). Ultra-low gelling agarose was purchased from BDH Electran, BDH laboratory supplies (Poole, England; 44415 2G). Propidium iodide (PI) and 4',6-diamidino-2-phenylindole (DAPI) were obtained from Sigma Aldrich Chemicals Pvt Ltd (Bangalore, Karnataka, India). Boric acid was purchased from Glaxo Laboratories Ltd (Mumbai, Maharashtra, India). Phosphate buffered saline $\left(\mathrm{Ca}^{2+}, \mathrm{Mg}^{2+}\right.$ free PBS), Trypan blue, 2-Thiobarbituric acid (TBA), Trichloroacetic acid (TCA), Ellman's reagent (DTNB reagent-5,5'-Dithiobis-[2-Nitro Benzoic Acid]) were obtained from Himedia Pvt Ltd (Mumbai, Maharashtra, India). Sodium pertechnetate $\left(\mathrm{NaTcO}_{4}{ }^{-}\right)$freshly eluted from molybdenum-99 $\left({ }^{99} \mathrm{Mo}\right)$ by solvent extraction, was obtained from the Regional centre for Radiopharmaceutical division, Board of Radiation and Isotope Technology (BRIT), Institute of Nuclear Medicine and Allied Sciences (INMAS), Delhi, India. Instant thin layer chromatography sheets coated with silica gel (ITLC-SG) were obtained from Gelman Sciences Inc., (Ann Arbor, MI). All other chemicals used in the present study were obtained of analytical reagent grade.

\subsection{Methods}

\subsubsection{Preparation of PEG-PLA NPs dispersion}

PEG-PLA NPs dispersion was prepared from its copolymer by nanoprecipitation method. Briefly, the organic phase prepared by dissolving copolymer in an organic solvent namely acetone $(5 \mathrm{mg} / 0.5 \mathrm{ml})$ was added drop-wise to the aqueous phase made by dissolving sodium cholate (surfactant) in milli Q-water $(1 \mathrm{mg} / \mathrm{ml})$, under magnetic stirring leading to their coprecipitation as nano-objects in the resulting solvent/water mixture. Acetone was then removed by evaporation under reduced pressure $\left(200 \mathrm{bar}\right.$ ) at $37^{\circ} \mathrm{C}$ using rotavapor (Boeco rotary evaporator RVO $400 \mathrm{SD}$, Germany) to obtain an organic solvent-free nanodispersion.

\subsubsection{Physicochemical Characterization of PEG-PLA NPs}

The morphology (size, shape) of PEG-PLA NPs was examined by transmission electron microscopy (TEM). A drop of appropriately diluted NPs samples with double distilled water were loaded onto the copper grid and allowed to dry at room temperature followed by staining with $2 \%$ (weight) phosphotungstic acid. Then, they were examined under transmission electron microscope (TECNAI-200 kV, FEI Netherlands) at an accelerating voltage of $80 \mathrm{kV}$.

\subsubsection{Radiolabeling of PEG-PLA NPs}

PEG-PLA NPs were radiolabeled with ${ }^{99} \mathrm{~m}$ Tc by reduction with $\mathrm{SnCl}_{2} 2 \mathrm{H}_{2} \mathrm{O}$ as per the previously reported methods (Richardson et al., 1977 \& Reddy et al., 2005) and the 
parameters such as $\mathrm{SnCl}_{2}$ concentration $(25-150 \mu \mathrm{g}), \mathrm{pH}$ (5.0-8.0) and incubation time (0-40 min) required to achieve maximum labeling efficiency were optimized. Briefly, the $\mathrm{NaTcO}_{4}{ }^{-}$ $\left(\sim 2 \mathrm{mCi}\right.$ ) was reduced with $100 \mu \mathrm{g} \mathrm{SnCl}_{2} 2 \mathrm{H}_{2} \mathrm{O}$ (prepared in $0.1 \mathrm{~N} \mathrm{HCl}$ ) and the $\mathrm{pH}$ was adjusted to 7.0 with $0.5 \mathrm{M}$ sodium bicarbonate solution. To it, PEG-PLA NPs dispersion (5 $\mathrm{mg} / \mathrm{ml}$ ) was added and incubated at room temperature for $20 \mathrm{~min}$. The quality control was performed as reported previously [16]. The labeling efficiency of ${ }^{99 \mathrm{~m}}$ Tc-PEG-PLA NPs complex was determined using ITLC-SG sheets by ascending ITLC and was performed by placing approximately $3 \mu \mathrm{l}$ of labeled complex at $1 \mathrm{~cm}$ above the bottom of the ITLC-SG strip and developed using acetone as the mobile phase. The solvent front was permitted to arrive up to a height of $8 \mathrm{cms}$ from the spotting. The strip was cut into two halves and the radioactivity in each half was measured using a well-type gamma ray spectrometer (CAPRAC-R, Capintec, NJ, USA). The free pertechnetate $\left(\mathrm{TcO}_{4}^{-}\right)$migrates to the top part of the ITLC-SG strip $\left(\mathrm{R}_{\mathrm{f}}=0.9-1.0\right)$, leaving the reduced/hydrolyzed ${ }^{99 \mathrm{~m}} \mathrm{Tc}$ along with the labeled complex at the bottom. Usage of excess $\mathrm{SnCl}_{2}$ for $\mathrm{TcO}_{4}{ }^{-}$reduction may lead to the formation of undesirable radiocolloids. The colloid formation was determined in acetone:saline $(0.9 \%$ sodium chloride) (1:1) in which radiocolloids remained at the bottom of the strip, whereas, both free $\mathrm{TcO}_{4}{ }^{-}$and the labeled complex migrated with the solvent front. The net amount of ${ }^{99 m}$ Tc-PEG-PLA NP complex was calculated by subtracting the migration with the solvent front using acetone, from that using acetone:saline.

\subsubsection{Stability study of the ${ }^{99 m}$ Tc -PEG-PLA NPs complex}

\subsubsection{Stability of labeled complex in serum}

Determining the stability of labeled complex in serum in vitro is an important factor because the serum contains proteins which may chelate and bind to ${ }^{99 \mathrm{~m}} \mathrm{Tc}$, disturbing the stability of labeled complexes. Thus, the stability of labeled complexes post-administration into the body is supported by their stability in serum. The stability of ${ }^{99 \mathrm{~m}}$ Tc-PEG-PLA NPs complex was determined in human serum and also in physiological saline by ascending ITLC. $0.3 \mathrm{ml}$ of labeled complex was incubated with $0.6 \mathrm{ml}$ of freshly collected human serum and saline separately at $37^{\circ} \mathrm{C}$. The stability was determined based on the changes in labeling efficiency by subjecting the samples to ITLC at different intervals up to $24 \mathrm{~h}$ and analyzing the chromatograms in gamma ray spectrometer.

\subsubsection{Stability of labeled complex in presence of DTPA and cysteine}

In vitro stability of ${ }^{99 \mathrm{~m}}$ Tc-PEG-PLA NPs complex with chelating agents such as DTPA and cysteine was performed as reported previously (Reddy et al., 2005). Briefly, $0.5 \mathrm{ml}$ of labeled complex was incubated with freshly prepared solutions of DTPA and cysteine $(10,25,50,75$ and $100 \mathrm{mM}$ in saline) for $1 \mathrm{~h}$ at $37^{\circ} \mathrm{C} .0 .5 \mathrm{ml}$ of saline served as control. The effect of DTPA on the labeling efficiency of complexes was measured on ITLC-SG strips using acetone as mobile phase, which allowed the movement of free $\mathrm{TcO}_{4}{ }^{-}$and ${ }^{99 \mathrm{~m}} \mathrm{Tc}-\mathrm{DTPA}$ complex $\left(\mathrm{R}_{\mathrm{f}}=0.8\right.$ 1.0) to the top of strip, whereas ${ }^{99 m}$ Tc-PEG-PLA NPs complex remained at the spotting $\left(\mathrm{R}_{\mathrm{f}=0}\right.$ ). For cysteine $0.1 \mathrm{M}$ PBS (pH 7.4) was used as the mobile phase. Free $\mathrm{TcO}_{4}{ }^{-}$and ${ }^{99 \mathrm{~m}} \mathrm{Tc}-$ cysteine complex migrated with the solvent front whereas the labeled complex remained at the origin.

\subsubsection{Animals and treatment}

All animal handling procedures and experiments were carried out as per the regulations of Institutional Animal Ethics Committee (IAEC), Institute of Nuclear Medicine and Allied Sciences (INMAS), Delhi with their formal consent for using the animals. Male Swiss albino mice ( 6 -weeks old, $27 \pm 3 \mathrm{~g}$ ) were obtained from INMAS Animal house central facility and housed under standard conditions (temperature $23 \pm 2^{\circ} \mathrm{C}$, relative humidity $55 \pm 5 \%$ and $12 \mathrm{~h}$ 
light/dark cycle). They had free access to water but deprived of food overnight prior to the treatment. The NP doses were administered in fasting state to avoid possible food effect on absorption of NPs from gastrointestinal tract (GIT).

\subsubsection{Blood kinetics}

Blood kinetics of ${ }^{99 m}$ Tc-PEG-PLA NPs complex was studied in Sprague Dawley rats weighing about $250-300 \mathrm{gm} . \sim 0.15 \mathrm{mCi}$ of the labeled complex was injected i.v. through tail vein, and blood was collected from the retro-orbital plexus of eye at different time intervals such as $0.01,0.05,0.5,1,2,4$ and $24 \mathrm{~h}$, and measured the radioactivity per gram of blood by assuming the total blood as $7.3 \%$ of the total body weight.

\subsubsection{Biodistribution study}

Mice were treated with ${ }^{99 \mathrm{~m}}$ Tc-PEG-PLA NPs complex separately at $20 \mathrm{mg} / \mathrm{kg}$ and $40 \mathrm{mg} / \mathrm{kg}$ body weight i.v. and by oral route, and the biodistribution study was performed at 1, 2, 4 and $24 \mathrm{~h}$ post-injection. At these time intervals, blood was collected by cardiac puncture, mice were sacrificed and the organs were isolated. The organs were blotted with tissue paper to remove adhered blood, weighed, and the radioactivity was measured using gamma ray spectrometer. The radioactivity was interpreted as percent injected dose (\% ID) per gram of organ/ tissue. To correct for physical decay of radioactive material and to calculate the uptake of radiolabeled complex in each organ as a fraction of the injected dose, aliquots of the labeled complex containing $2 \%$ of the ID, were counted concurrently at each time point.

\subsubsection{Gamma scintigraphy}

The biodistribution pattern of ${ }^{99 m}$ Tc-PEG-PLA NPs complex in rat was recorded with single photon emission computed tomography (SPECT, LC 75-005, Diacam, USA) gamma camera following i.v. injection of $0.1 \mathrm{mCi}$ of the labeled moiety. At $4 \mathrm{~h}$ and $24 \mathrm{~h}$ post injection, the mice were anesthetized by i.v. injection of KETAMAX*50, fixed on animal fixing tray board and imaging was performed at these time intervals using SPECT gamma camera.

For determination of hematological and serum biochemical parameters, measurement of oxidative stress, genotoxicity and histopathological alterations, unlabeled PEG-PLA NPs (40 $\mathrm{mg} / \mathrm{kg}$ dose) were administered into mice through i.v. and oral routes. Mice treated with water were used as control (untreated). After $72 \mathrm{~h}$, the animals were anesthetized, blood was collected by cardiac puncture and used for hematology and serum biochemistry assays. The mice were sacrificed, the organs were isolated and used for experiments.

\subsubsection{Hemocompatibility}

The whole blood collected from mice was mixed with disodium EDTA and analyzed for hematological parameters such as Red blood cell (RBC) count, Hemoglobin (Hgb), Hematocrit (HCT), Mean corpuscular volume (MCV), Mean corpuscular Hgb (MCH), Mean corpuscular Hgb concentration (MCHC), Red cell distribution width (RDW), White blood cell (WBC) count, Platelet count, Mean platelet volume (MPV), Plateletcrit (PCT) using Automated Hematology Analyzer (CELLTAC a NIHON KOHDEN, MEK-6450K, Japan). Serum obtained by centrifugation of whole blood at $2500 \mathrm{rpm}$ for $15 \mathrm{~min}$ was used for estimation of biochemical parameters such as serum glutamate oxaloacetate transaminase (SGOT), serum glutamate pyruvate transaminase (SGPT), creatinine, bilirubin and urea by a fully Automated Biochemistry Analyzer (Roche, Hitachi 902, Manheim, Germany). Standard controls were run before each assay.

\subsubsection{Oxidative stress}

Markers of oxidative stress such as lipid peroxidation and glutathione levels were assessed in mice administered with PEG-PLA NPs through i.v and oral routes. 


\subsubsection{Lipid Peroxidation (LPO) assay}

LPO in the liver, spleen, kidney tissues of mice untreated and treated i.v.; liver, stomach, intestine of untreated and mice administered with PEG-PLA NPs orally was assessed using TBA method as described by Laughton et al., 1989. A 10\% (w/v) homogenate of tissues were prepared in $0.1 \mathrm{M}$ ice cold PBS ( $\mathrm{pH}$ 7.4) by homogenization using hand-held homogenizer (IKA T10, Germany). $600 \mu \mathrm{l}$ of tissue homogenate was incubated with $100 \mu \mathrm{l}$ of TCA (10\% $\mathrm{w} / \mathrm{v}$ ) at $37^{\circ} \mathrm{C}$ for $1 \mathrm{~h}$ and centrifuged at $1000 \mathrm{xg}$ in a refrigerated centrifuge (Combi 514R, Hanil, South Korea) for $10 \mathrm{~min}$ at room temperature. To the supernatant, $100 \mu \mathrm{l}$ of TBA $(0.67 \% \mathrm{w} / \mathrm{v}$ in $0.025 \mathrm{M} \mathrm{NaOH})$ was added and incubated at $80^{\circ} \mathrm{C}$ for $30 \mathrm{~min}$. The absorbance of the resultant pink coloured TBA-Malondialdehyde (MDA) complex was measured at 535 nm using Gen5 software (Powerwave XS2, Biotek, USA). The degree of LPO was expressed as micromoles $(\mu \mathrm{M})$ of $\mathrm{MDA} / \mathrm{mg}$ of protein. Total protein content in the supernatants obtained by centrifugation of tissue homogenates was estimated by Bradford's method.

\subsubsection{Total Glutathione (GSH) measurement}

GSH levels in the tissue samples of liver, spleen, kidney of untreated and mice injected i.v., liver, stomach, intestine of untreated and mice orally administered with PLA-PEG NPs were estimated using Ellman's reagent as described by Beutler et al., 1963. Tissue homogenates prepared in section 2.2.10.1 were centrifuged at $8,000 \mathrm{xg}$ for $10 \mathrm{~min}$ at $4^{\circ} \mathrm{C}$. The supernatants obtained were treated with precipitating reagent (in 1:2 ratio) containing metaphosphoric acid, disodium EDTA and sodium chloride and then centrifuged at 2500xg for $10 \mathrm{~min} .200 \mu \mathrm{l}$ of supernatant was mixed with $650 \mu \mathrm{l}$ disodium hydrogen phosphate $\left(\mathrm{Na}_{2} \mathrm{HPO}_{4}\right)$ buffer $(0.3 \mathrm{M})$ and $150 \mu \mathrm{l}$ Ellman's reagent and measured the absorbance of yellow color developed

at $412 \mathrm{~nm}$. Blank without sample was prepared similarly and absorbance was recorded at 412 nm.

\subsubsection{Genotoxicity}

The genotoxic potential of PEG-PLA NPs was assessed by comet assay and micronuclei (MN) assay.

\subsubsection{Single cell gel electrophoresis assay (Comet assay)}

Liver, spleen, kidney tissues of untreated and mice injected i.v., liver, stomach, intestine of untreated and mice treated orally with PLA-PEG NPs were minced and single cell suspensions were prepared in $0.1 \mathrm{M}$ chilled PBS. Viability of the single cells was checked as per the guidelines of Tice et al., 2000. Single cells isolated from all the organs were diluted with PBS and viability was checked with $0.4 \%$ trypan blue dye. The cells with intact cell membrane excluded the dye considered as viable and were counted using hemocytometer under inverted phase contrast microscope (CKX 31, Olympus corporation, Japan). Comet assay was performed as described previously by Khaitan et al., 2006. Briefly, a cell suspension containing approximately 10,000 cells mixed with pre-warmed $0.75 \%$ ultra-low gelling agarose was layered onto microscopic slides pre-coated with $0.1 \%$ NMA and incubated at $4^{\circ} \mathrm{C}$ for $10 \mathrm{~min}$. Lysis was performed by placing the slides in neutral lysis buffer (2.5\% sodium dodecyl sulfate, $1 \%$ SLS, $25 \mathrm{mM}$ EDTA; $\mathrm{pH} 9.5$ ) for $15 \mathrm{~min}$ at $25-30^{\circ} \mathrm{C}$. Slides were then washed in distilled water for $5 \mathrm{~min}$ and electrophoresis was performed at $2 \mathrm{~V} / \mathrm{cm}(400 \mathrm{~mA})$ for $5 \mathrm{~min}$ at $10^{\circ} \mathrm{C}$ in electrophoresis buffer $(90 \mathrm{mM}$ Tris base, $90 \mathrm{mM}$ Boric acid, $2.5 \mathrm{mM}$ EDTA; $\mathrm{pH}$ 8.4). Slides were rinsed again in distilled water for $5 \mathrm{~min}$, air dried at $45^{\circ} \mathrm{C}$ on a hot plate and stored in a cool humid box until use. Following rehydration in distilled water, comets were stained with PI (50 $\mu \mathrm{g} / \mathrm{ml}$ in PBS) and images were acquired in fluorescence microscope (BX60, Olympus, Japan) with appropriate fluorescence filter (WG; Olympus) using FA87 monochrome CCD camera (Grunding, Germany) and Optimas Image 
Analysis Software (Optimas USA; version 5.2). The comet parameters such as olive tail moment (OTM) and \% Tail DNA were recorded to measure DNA damage in the cells. Analysis of DNA distribution in the comets was performed using Komet 5.5 software, Kinetic imaging, USA.

\subsubsection{Micronuclei (MN) assay}

MN assay of liver, spleen, and kidney tissues isolated from untreated and mice treated i.v., liver, stomach, intestine of untreated and mice treated orally with PEG-PLA NPs was performed as described previously (Khaitan et al., 2006) using DAPI method. Air-dried slides containing methanol:acetic acid $(3: 1 \mathrm{v} / \mathrm{v})$ fixed cells of the tissues were stained with a DNA specific fluorochrome DAPI $(3 \mu \mathrm{g} / \mathrm{ml})$. Slides were then examined under fluorescence microscope using UV excitation filter and fluorescing nuclei were visualized under blue emission filter. Cells containing $\mathrm{MN}$ were counted from $>1000$ binucleated cells by employing the criteria of Countryman \& Heddle., 1976. The fraction of cells containing MN (M-fraction \%) was calculated as follows:

M-fraction $\%=\mathrm{N}_{\mathrm{m}} / \mathrm{N}_{\mathrm{t}} \mathrm{X100}$, where $\mathrm{N}_{\mathrm{m}}$ is the number of cells containing micronuclei and $\mathrm{N}_{\mathrm{t}}$ is the total number of cells analyzed.

\subsubsection{Histopathological studies}

The tissues namely liver, spleen, kidney and lung isolated from untreated and mice i.v. injected with PEG-PLA NPs, stomach and intestine isolated from untreated and mice orally administered with PEG-PLA NPs were fixed in $10 \%$ formalin for $48 \mathrm{~h}$ at room temperature. Dehydration of tissues using different concentrations of alcohol $(70 \%, 80 \%, 95 \%$ and $100 \%)$ and the subsequent removal of the dehydrating agent by xylene were carried out using Automatic Tissue Processor (Spencers, Model No. 1040-STP-004). The dehydrated tissues were then embedded in paraffin blocks in Tissue Embedding System (Spencers, Model No. 3080-STE-004), which were then sliced into $5 \mu \mathrm{m}$ thick sections using microtome blade and subsequently placed onto clean glass slides. Following hematoxylin-eosin (H\&E) staining, the slides were examined by light microscopy for histopathological changes.

\subsubsection{Statistical analysis}

Data represents mean and standard error of the mean (SEM) from seven biological replicates for each group of experimental mice. The data were analyzed by means of Student's $t$-test and one-way analysis of variance (ANOVA) with Dunnett's test wherever applicable to determine the significant difference between treated and untreated groups using Graph pad prism 6.05 (Graph pad software, Inc., La Jolla, CA, USA). P value less than $0.05(p<0.05)$ was considered statistically significant in all the cases.

\section{Results and Discussion}

PEG-PLA NPs are one of the promising candidates for drug delivery by i.v. (e.g. small therapeutic molecules) (Autio et al., 2018) and oral routes (e.g. peptides) (Pridgen et al., 2013) due to their biocompatibility and their ability to exhibit longer systemic half-life after i.v. injection. When administered through oral route, these NPs were shown to protect the encapsulated drug payload from the aggressive gastro-intestinal environment (Tobio et al., 2000). This study demonstrated the biodistribution pattern of PEG-PLA NPs following i.v. and oral routes of administration in mice and also the influence of administration route on induction of oxidative stress, DNA damage, hematological and histopathological effects of PEG-PLA NPs. 


\subsection{Characterization of PEG-PLA NPs}

TEM highlighted the spherical morphology of PEG-PLA NPs as shown in Figure 1. The size of NPs obtained was 100-150 $\mathrm{nm}$.

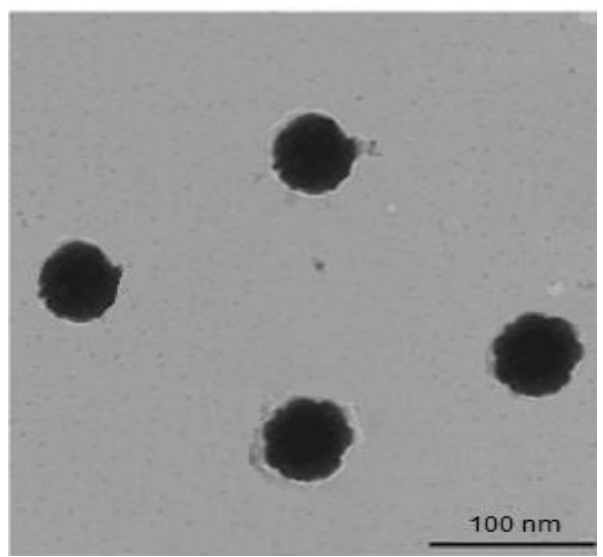

Figure 1. Transmission electron microscopy (TEM) image of PEG-PLA NPs

\subsection{Radiolabeling and in vitro stability studies}

Radiolabeling experiments revealed that PEG-PLA NPs were labeled with ${ }^{99 \mathrm{~m}} \mathrm{Tc}$ with maximum labeling efficiency. The $\mathrm{SnCl}_{2}$ concentration above the optimum leads to undesirable colloids formation which distribute widely to the RES organs due to the uptake by macrophages, whereas the concentration of $\mathrm{SnCl}_{2}$ below the optimum results in poor labeling efficiency due to the partial reduction of $\mathrm{TcO}_{4}{ }^{-}$from its heptavalent oxidation state (Reddy et al., 2005). Thus, the concentration of $\mathrm{SnCl}_{2}$ used for the reduction of $\mathrm{TcO}_{4}{ }^{-}$played a key role in the labeling procedure. Hence, studies were carried out using different concentrations of $\mathrm{SnCl}_{2}$ to optimize maximum labeling efficiency (Table 1(a)). The effect of $\mathrm{pH}$ and incubation time on labeling efficiency is shown in Table 1 ((b) and (c)). The optimal concentration of $\mathrm{SnCl}_{2}$ that resulted in maximum labeling efficiency and low quantity of radiocolloids was $100 \mu \mathrm{g}$ at $\mathrm{pH} 7.0$ and incubation period of $20 \mathrm{~min}$.

Table 1.

(a) Influence of $\mathrm{SnCl}_{2}$ concentration on labeling efficiency of PEG-PLA NPs

\begin{tabular}{cccc}
\hline $\mathbf{S n C l}_{2.2 \mathbf{H}_{\mathbf{2}}(\boldsymbol{\mu g})}$ & \% Labeled & \% Colloids & \% Free \\
\hline 25 & $81.57 \pm 1.10$ & $0.19 \pm 0.018$ & $18.24 \pm 1.08$ \\
50 & $89.0 \pm 1.15$ & $0.27 \pm 0.01$ & $10.73 \pm 1.16$ \\
75 & $93.13 \pm 0.46$ & $0.38 \pm 0.005$ & $6.49 \pm 0.47$ \\
100 & $99.57 \pm 0.06$ & $0.40 \pm 0.05$ & $0.03 \pm 0.008$ \\
150 & $95.10 \pm 0.94$ & $4.49 \pm 0.92$ & $0.41 \pm 0.1$ \\
\hline
\end{tabular}

(b) Effect of $\mathrm{pH}$ on labeling efficiency of PEG-PLA NPS

\begin{tabular}{ll}
\hline $\mathbf{p H}$ & \% Radiolabeled \\
\hline 5 & $92.3 \pm 0.88$ \\
5.5 & $94.3 \pm 0.88$ \\
6 & $97.3 \pm 0.66$ \\
6.5 & $97.7 \pm 0.39$ \\
7 & $99.5 \pm 0.11$ \\
7.5 & $95.8 \pm 0.44$ \\
8 & $93 \pm 1.15$ \\
\hline
\end{tabular}


(c) Effect of incubation period on labeling efficiency of PEG-PLA NPS

\begin{tabular}{cl}
\hline $\begin{array}{c}\text { Incubation time } \\
(\text { min })\end{array}$ & \% Radiolabeled \\
\hline 0 & $57.3 \pm 1.45$ \\
5 & $73.3 \pm 3.75$ \\
10 & $78.3 \pm 2.6$ \\
15 & $94 \pm 1.15$ \\
20 & $99.5 \pm 0.12$ \\
30 & $95.3 \pm 0.88$ \\
40 & $91 \pm 1.15$ \\
\hline
\end{tabular}

Determination of stability of the labeled complex in serum is an important factor, which promises the integrity of the labeled complex in presence of serum components. In vitro stability data of ${ }^{99 \mathrm{~m}}$ Tc-PEG-PLA NP complex in serum and saline shown in Table 2 revealed that approximately $98 \%$ labeling efficiency was retained in serum and physiological saline even at $24 \mathrm{~h}$ time point. The labeled PEG-PLA NPs were found to be highly stable in serum and also in physiological saline as signified by their greater labeling efficiency.

Table 2.

Stability of ${ }^{99 m} T c-P E G-P L A N P$ s complex in serum and saline

\begin{tabular}{ccc}
\hline \multirow{2}{*}{ Time (h) } & \multicolumn{2}{c}{ \% Radiolabeling } \\
In Human Serum & In Saline \\
\hline 0 & $99.4 \pm 0.17$ & $99.1 \pm 0.17$ \\
0.5 & $99.2 \pm 0.17$ & $99 \pm 0.17$ \\
1 & $99 \pm 0.14$ & $98.9 \pm 0.1$ \\
2 & $99 \pm 0.11$ & $98.7 \pm 0.4$ \\
4 & $99 \pm 0.17$ & $98.5 \pm 0.28$ \\
6 & $99 \pm 0.31$ & $98.2 \pm 0.08$ \\
24 & $98.6 \pm 0.31$ & $98.2 \pm 0.4$ \\
\hline
\end{tabular}

The stability of the labeled complex in presence of DTPA and cysteine was assessed to evaluate whether the labeling efficiency is altered in the presence of these transchelating agents. These agents exhibit high affinity for ${ }^{99 \mathrm{~m}} \mathrm{Tc}$, and hence cause transchelation on incubation with labeled complex resulting in reduced labeling. Low level of transchelation of the labeled complex indicate their in vitro stability. Transchelation studies with DTPA and cysteine revealed that the labeling efficiency was not changed much in the presence of these transchelating agents (Figure 2). Even at $100 \mathrm{mM}$ concentration of these agents, transchelation was found to be less than $8 \%$, supporting the stability of labeled complex in vitro.

PEG-PLA NPs possess two binding sites on PLA moiety for ${ }^{99 \mathrm{~m}} \mathrm{Tc}$, namely oxygen atom of carboxyl group and oxygen atom of hydroxyl group, which can participate in coordination. Possibly, two molecules of PEG-PLA NPs bind with ${ }^{99 \mathrm{~m}} \mathrm{Tc}$ to form stable complexes as shown in Figure 3. 


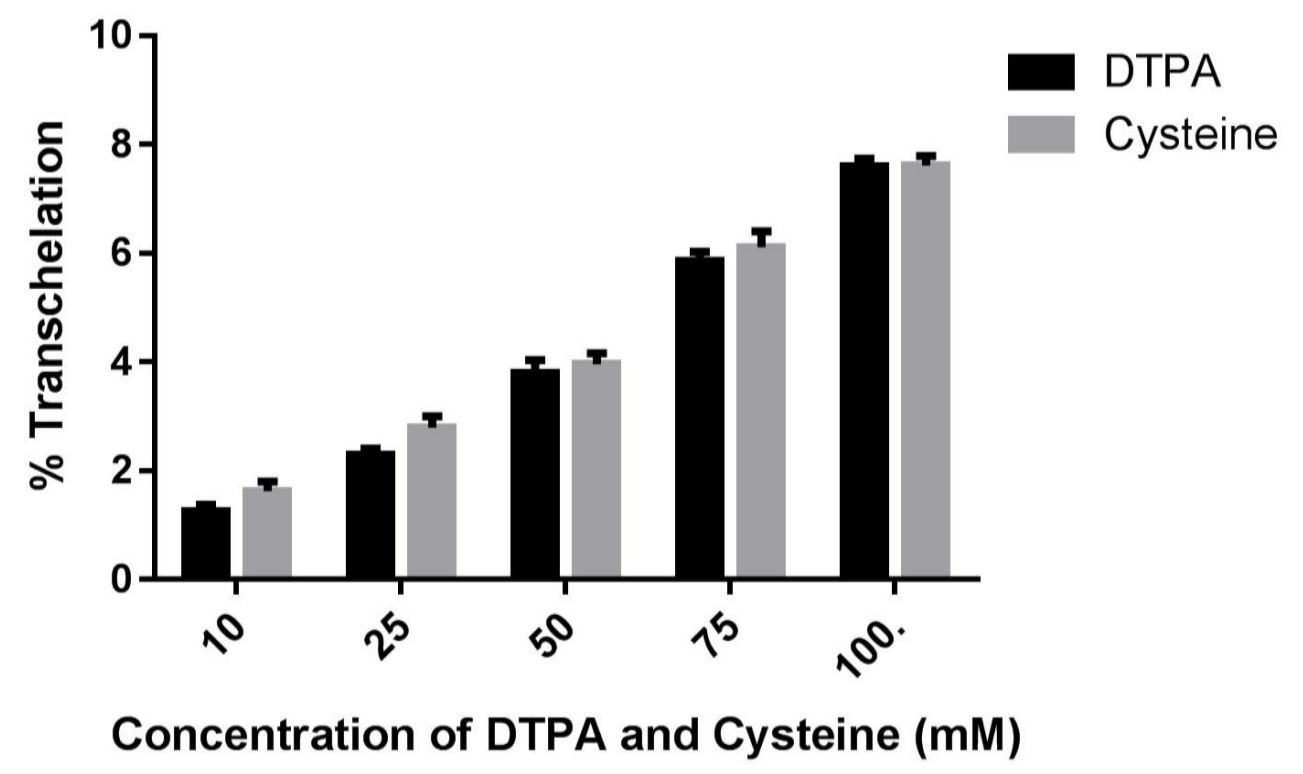

Figure 2. Stability of ${ }^{99 \mathrm{~m}}$ Tc-PEG-PLA NPs complex in presence of transchelating agents.

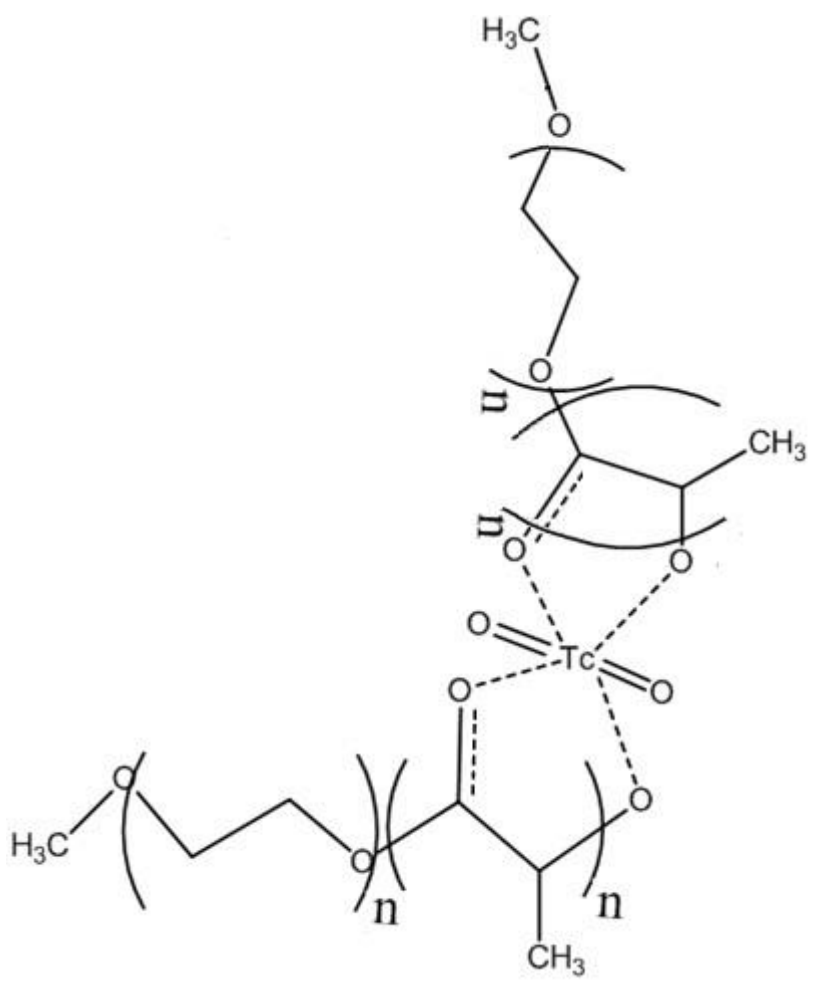

Figure 3. Structure of ${ }^{99 \mathrm{~m}}$ Tc-PEG-PLA NPs complex

\subsection{Blood kinetics}

Blood kinetics of ${ }^{99}$ Tc-PEG-PLA NPs complex following i.v. injection in rat is shown in Figure 4. It is evident that NP clearance was low initially up to $0.25 \mathrm{~h}$ and increased significantly after $0.5 \mathrm{~h}$. At $1 \mathrm{~h}$ post-injection, 33\% ID was detected in blood. Even at $24 \mathrm{~h}$, $8 \%$ ID was recovered, indicating the prolonged systemic circulation of PEG-PLA NPs. 


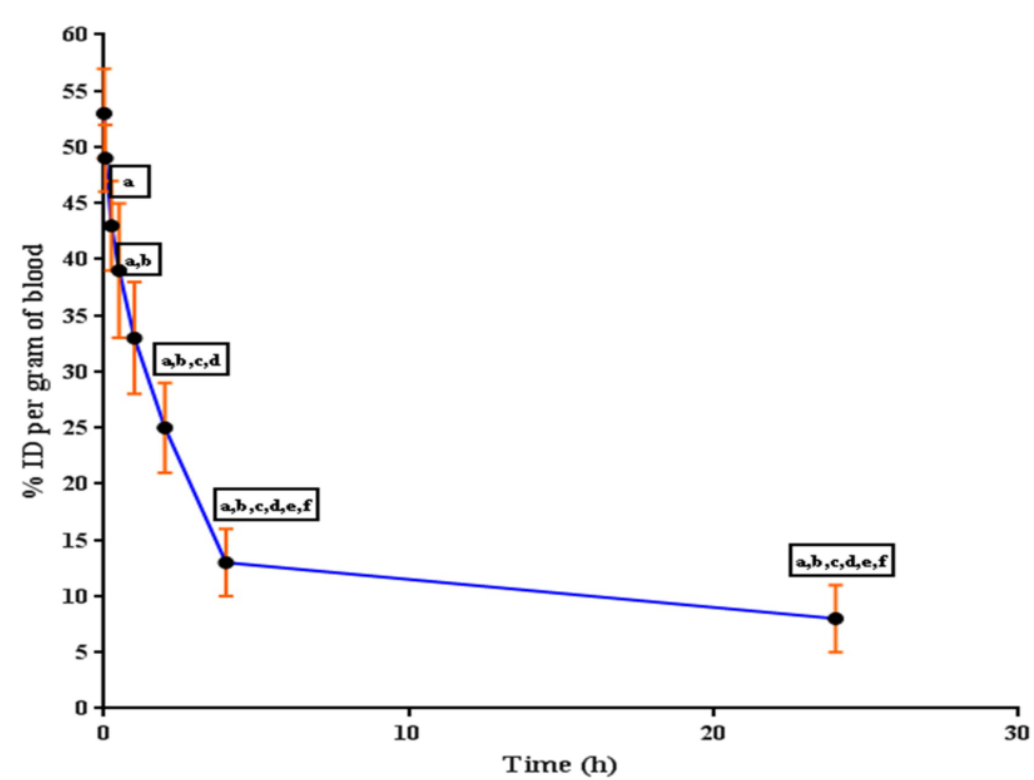

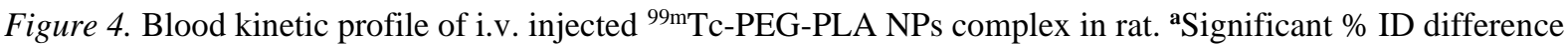
compared to $0.01 \mathrm{~h}$; ${ }^{\mathrm{b}}$ Significant $\%$ ID difference compared to $0.05 \mathrm{~h}$; ${ }^{\mathrm{c}}$ Significant $\%$ ID difference compared to

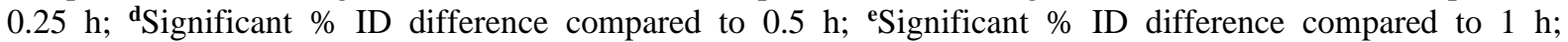
fSignificant \% ID difference compared to 2 h. $p<0.05$ was considered statistically significant in all the cases

\subsection{Biodistribution studies}

Biodistribution studies of ${ }^{99 \mathrm{~m}}$ Tc-PEG-PLA NPs complex were performed in mice at 1, 2, 4 and $24 \mathrm{~h}$ time points following i.v. injection and oral administration. Biodistribution pattern of i.v. injected NPs in blood and the organs of reticuloendothelial system (RES) such as liver, spleen, lung and kidney is shown in Figure 5 and Table 3.

The biological fate of ${ }^{99 m}$ Tc-PEG-PLA NPs complex was different following i.v. and oral routes of administrations. After i.v. injection, higher concentrations of NPs were found in blood followed by liver, kidney, lung and spleen. At different time points tested, significantly higher radioactivity was observed in blood of $40 \mathrm{mg} / \mathrm{kg}$ body weight injected mice compared to $20 \mathrm{mg} / \mathrm{kg}$ body weight at 1,2 and $4 \mathrm{~h}$ time intervals. Even though radioactivity in blood decreased significantly at $24 \mathrm{~h}, 5.43 \%$ and $7.33 \%$ ID was detected at $24 \mathrm{~h}$ post injection in 20 and $40 \mathrm{mg} / \mathrm{Kg}$ doses treated mice. The dose dependent distribution of NPs was considerably higher in liver than in spleen at all the time points tested. A significant dose-dependent distribution of radiolabeled NPs was observed in spleen at all-time points. The higher concentration of NPs detected in blood compared to RES organs at different time points could be due to the reduced macrophage uptake of these NPs (as PEG coating dramatically enhances the plasma half-life of PEG-PLA NPs) (Verrecchia et al., 1995). Moreover, a dosedependent distribution of NPs was found in blood and also in RES organs. NP distribution was found to reduce with time in the organs of RES such as liver, spleen and kidney.

Uptake of radiolabeled NPs by lungs slightly increased from 1 to $4 \mathrm{~h}$ post-injection but decreased at $24 \mathrm{~h}$ post injection. However, significantly higher concentrations of NPs were observed in the lungs of mice injected with $40 \mathrm{mg} / \mathrm{kg}$ body weight compared to $20 \mathrm{mg} / \mathrm{kg}$ body weight at all the time points. indicating the rapid distribution of NPs from blood to the lung. Radioactivity in kidney decreased gradually and the dose-dependent \% ID difference was significant at $1 \mathrm{~h}$ and $2 \mathrm{~h}$ time intervals. Low radioactivity in the stomach and intestine of mice injected i.v. with radiolabeled NPs supports the in vivo stability of the labeled complex. A high radioactivity in these organs may have indicated a dissociation of the label and consequent accumulation of free technetium in these organs. The increased radioactivity in brain at $24 \mathrm{~h}$ post injection in 20 and $40 \mathrm{mg} / \mathrm{kg}$ body weight treated mice indicated a progressive distribution of NPs to this organ. 


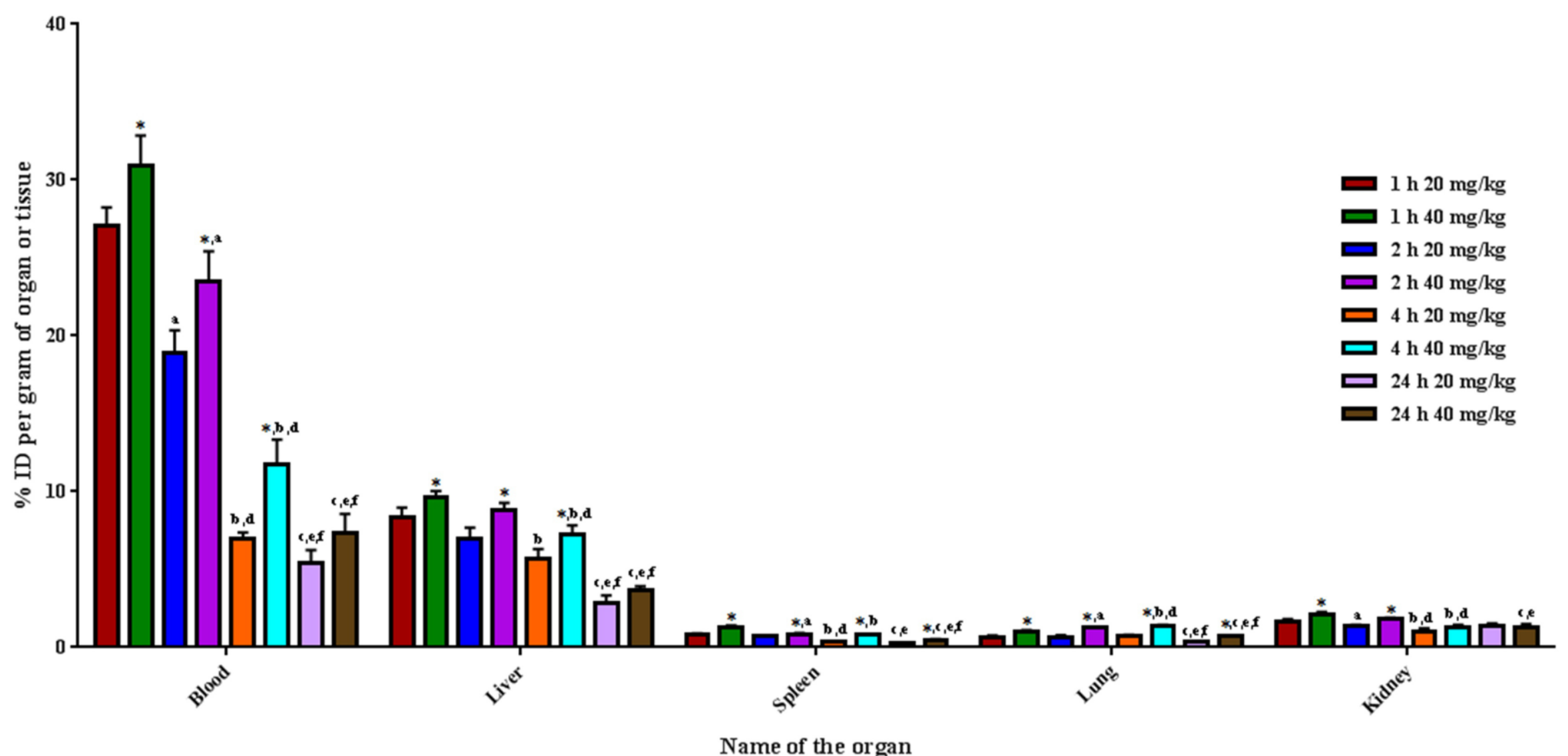

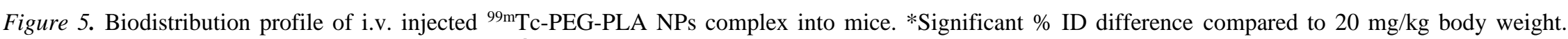
${ }^{a}$ Significant $\%$ ID difference between $1 \mathrm{~h}$ and $2 \mathrm{~h}$; ${ }^{\mathrm{b}}$ Significant $\%$ ID difference between $1 \mathrm{~h}$ and $4 \mathrm{~h}$; 'Significant \% ID difference between $1 \mathrm{~h}$ and $24 \mathrm{~h}$;

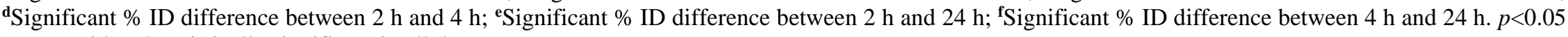
was considered statistically significant in all the cases. 
Table 3.

Biodistribution pattern of i.v. injected ${ }^{99 m}$ Tc-PEG-PLA NPs complex in mice

\begin{tabular}{|c|c|c|c|c|c|c|c|c|c|}
\hline \multirow{2}{*}{$\begin{array}{l}\text { S. } \\
\text { No }\end{array}$} & \multirow{2}{*}{$\begin{array}{l}\text { Name of } \\
\text { the organ }\end{array}$} & \multicolumn{2}{|c|}{$1 \mathrm{~h}$} & \multicolumn{2}{|c|}{$2 \mathrm{~h}$} & \multicolumn{2}{|c|}{$4 \mathrm{~h}$} & \multicolumn{2}{|c|}{$24 \mathrm{~h}$} \\
\hline & & $20 \mathrm{mg} / \mathrm{Kg}$ & $40 \mathrm{mg} / \mathrm{Kg}$ & $20 \mathrm{mg} / \mathrm{Kg}$ & $40 \mathrm{mg} / \mathrm{Kg}$ & $20 \mathrm{mg} / \mathrm{Kg}$ & $40 \mathrm{mg} / \mathrm{Kg}$ & $20 \mathrm{mg} / \mathrm{Kg}$ & $40 \mathrm{mg} / \mathrm{Kg}$ \\
\hline 1 & Heart & $0.58 \pm 0.03$ & $0.7 \pm 0.01 *$ & $0.55 \pm 0.02$ & $0.56 \pm 0.02^{\mathrm{a}}$ & $0.43 \pm 0.04$ & $0.47 \pm 0.03^{\mathbf{b}}$ & $0.38 \pm 0.02^{\mathbf{c}, \mathbf{e}}$ & $0.44 \pm 0.04^{\mathrm{c}}$ \\
\hline 2 & Muscle & $0.14 \pm 0.01$ & $0.34 \pm 0.11$ & $0.13 \pm 0.02$ & $0.14 \pm 0.008$ & $0.14 \pm 0.01$ & $0.13 \pm 0.01$ & $0.13 \pm 0.005$ & $0.13 \pm 0.01$ \\
\hline 3 & Bone & $0.61 \pm 0.05$ & $0.58 \pm 0.11$ & $0.35 \pm 0.04^{\mathrm{a}}$ & $0.34 \pm 0.03$ & $0.32 \pm 0.02^{\mathbf{b}}$ & $0.32 \pm 0.05$ & $0.23 \pm 0.01^{\mathbf{c}, \mathbf{f}}$ & $0.29 \pm 0.05$ \\
\hline 4 & Stomach & $0.58 \pm 0.07$ & $0.66 \pm 0.03$ & $0.27 \pm 0.03^{\mathrm{a}}$ & $0.43 \pm 0.07$ & $0.22 \pm 0.06^{\mathbf{b}}$ & $0.31 \pm 0.06^{\mathbf{b}}$ & $0.29 \pm 0.07$ & $0.59 \pm 0.06^{*, \mathbf{f}}$ \\
\hline 5 & Intestine & $1.13 \pm 0.31$ & $1.21 \pm 0.2$ & $0.5 \pm 0.07$ & $0.98 \pm 0.11 *$ & $0.53 \pm 0.05$ & $0.77 \pm 0.06$ & $0.5 \pm 0.07$ & $0.37 \pm 0.03^{\mathbf{c}, \mathbf{e , f}}$ \\
\hline 6 & Brain & $0.06 \pm 0.006$ & $0.09 \pm 0.01$ & $0.06 \pm 0.01$ & $0.13 \pm 0.01 *$ & $0.07 \pm 0.008$ & $0.12 \pm 0.01$ & $0.15 \pm 0.02^{\mathrm{c}, \mathrm{e}}$ & $0.24 \pm 0.02^{\mathbf{c}, \mathbf{e}, \mathbf{f}}$ \\
\hline
\end{tabular}

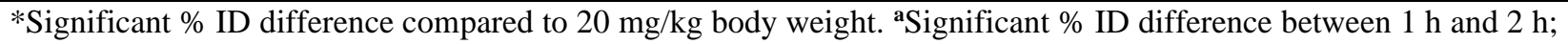
${ }^{\mathrm{b}}$ Significant \% ID difference between $1 \mathrm{~h}$ and $4 \mathrm{~h}$; 'Significant \% ID difference between $1 \mathrm{~h}$ and $24 \mathrm{~h}$; ${ }^{\mathrm{d}}$ Significant \%

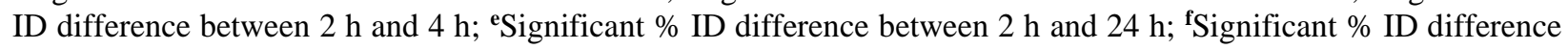
between $4 \mathrm{~h}$ and $24 \mathrm{~h} . \quad p<0.05$ was considered statistically significant in all the cases.

Biodistribution of orally administered ${ }^{99 m}$ Tc-PEG-PLA NPs is shown in Table 4. After oral administration, the concentration of NPs in all the organs studied was low initially except in stomach and in intestine. Higher concentrations of NPs were found in the stomach and intestine at $1 \mathrm{~h}$ post treatment. In stomach, radioactivity increased up to $2 \mathrm{~h}$ and then decreased progressively, whereas in intestine radioactivity gradually decreased from $1 \mathrm{~h}$ to $24 \mathrm{~h}$ time intervals. Dose-dependent distribution of NPs in the stomach was significant at 1,2 and $4 \mathrm{~h}$, whereas in intestine it was significant only at $1 \mathrm{~h}$ and $4 \mathrm{~h}$ time points. The decreased uptake of NPs by stomach and intestine at $24 \mathrm{~h}$ post-injection could be due to their excretion. Even though radioactivity in the stomach decreased at $24 \mathrm{~h}$ post-injection, $1.53 \%$ ID was retained in $40 \mathrm{mg} / \mathrm{kg}$ body weight administered mice, which was higher than the radioactivity observed in all the organs studied. 
Table 4.

Biodistribution result of ${ }^{99 m} T c-P E G-P L A N P$ s administered orally in mice.

\begin{tabular}{|c|c|c|c|c|c|c|c|c|c|}
\hline \multirow{2}{*}{$\begin{array}{l}\text { S. } \\
\text { No }\end{array}$} & \multirow{2}{*}{$\begin{array}{l}\text { Name of } \\
\text { the organ }\end{array}$} & \multicolumn{2}{|c|}{$1 \mathrm{~h}$} & \multicolumn{2}{|r|}{$2 \mathrm{~h}$} & \multicolumn{2}{|c|}{$4 h$} & \multicolumn{2}{|c|}{$24 \mathrm{~h}$} \\
\hline & & $20 \mathrm{mg} / \mathrm{Kg}$ & $40 \mathrm{mg} / \mathrm{Kg}$ & $20 \mathrm{mg} / \mathrm{Kg}$ & $40 \mathrm{mg} / \mathrm{Kg}$ & $20 \mathrm{mg} / \mathrm{Kg}$ & $40 \mathrm{mg} / \mathrm{Kg}$ & $20 \mathrm{mg} / \mathrm{Kg}$ & $40 \mathrm{mg} / \mathrm{Kg}$ \\
\hline 3 & Liver & $0.03 \pm 0.006$ & $0.033 \pm 0.009$ & $0.053 \pm 0.015$ & $0.027 \pm 0.009$ & $0.033 \pm 0.009$ & $0.03 \pm 0.006$ & $0.067 \pm 0.015$ & $0.053 \pm 0.015$ \\
\hline 4 & Lung & $0.02 \pm 0.006$ & $0.027 \pm 0.007$ & $0.03 \pm 0.006$ & $0.027 \pm 0.009$ & $0.04 \pm 0.006$ & $0.037 \pm 0.009$ & $0.063 \pm 0.01^{\mathrm{c}}$ & $0.27 \pm 0.03 * *, \mathbf{c e , e f}$ \\
\hline 5 & Spleen & $0.02 \pm 0.006$ & $0.027 \pm 0.009$ & $0.037 \pm 0.009$ & $0.02 \pm 0.006$ & $0.033 \pm 0.009$ & $0.023 \pm 0.009$ & $0.12 \pm 0.017^{\mathbf{c e}, \mathbf{f}}$ & $0.13 \pm 0.02^{\mathbf{c e , e f}}$ \\
\hline 7 & Muscle & $0.02 \pm 0.006$ & $0.027 \pm 0.009$ & $0.017 \pm 0.007$ & $0.067 \pm 0.015^{*}$ & $0.043 \pm 0.009$ & $0.027 \pm 0.012$ & $0.19 \pm 0.02^{\mathbf{c e , e f}}$ & $0.33 \pm 0.08^{\mathbf{c e , e f}}$ \\
\hline 8 & Bone & $0.03 \pm 0.012$ & $0.02 \pm 0.006$ & $0.03 \pm 0.006$ & $0.023 \pm 0.009$ & $0.027 \pm 0.009$ & $0.023 \pm 0.009$ & $0.067 \pm 0.01$ & $0.31 \pm 0.03^{*, \mathbf{c}, \mathbf{e}, \mathbf{f}}$ \\
\hline 9 & Stomach & $7.48 \pm 0.608$ & $25.71 \pm 2.40 * *$ & $17.42 \pm 1.27^{\mathrm{a}}$ & $35.81 \pm 2.15^{* *, \mathrm{a}}$ & $14.18 \pm 1.2^{\mathbf{b}}$ & $24.35 \pm 1.70^{* *, \mathbf{d}}$ & $0.163 \pm 0.04^{c, e, f}$ & $1.53 \pm 0.57^{\text {ce,ef }}$ \\
\hline 10 & Intestine & $7.75 \pm 0.73$ & $30.67 \pm 2.49 * * *$ & $2.31 \pm 0.34^{\mathrm{a}}$ & $2.82 \pm 0.17^{\mathrm{a}}$ & $0.64 \pm 0.07^{\mathbf{b}, \mathbf{d}}$ & $1.36 \pm 0.058^{* *, \mathbf{b}, \mathbf{d}}$ & $0.077 \pm 0.01^{c, e, f}$ & $0.043 \pm 0.015^{\text {ce,e,f }}$ \\
\hline 11 & Brain & $0.007 \pm 0.003$ & $0.01 \pm 0.006$ & $0.02 \pm 0.006$ & $0.007 \pm 0.003$ & $0.02 \pm 0.006$ & $0.01 \pm 0.006$ & $0.09 \pm 0.023^{\mathbf{c}, \mathbf{e}, \mathbf{f}}$ & $0.043 \pm 0.015$ \\
\hline
\end{tabular}

${ }^{*} p<0.05 ; * * p<0.01 ; * * * p<0.001$ indicates statistically significant difference in \% ID compared to $20 \mathrm{mg} / \mathrm{kg}$ body weight.

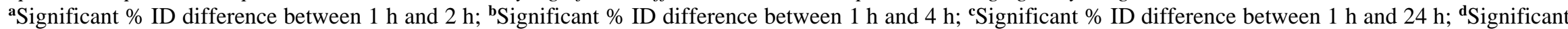

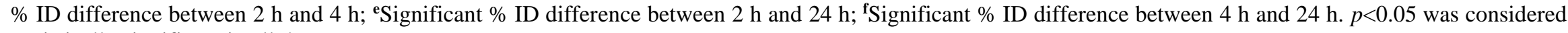
statistically significant in all the cases. 
In addition, $0.163 \%$ ID was detected in the stomach of mice treated with $20 \mathrm{mg} / \mathrm{kg}$ body weight at $24 \mathrm{~h}$ post-injection. which was higher than the radioactivity observed in all the organs next to muscle. In the blood of $20 \mathrm{mg} / \mathrm{kg}$ body weight treated mice, radioactivity significantly increased at 4 and $24 \mathrm{~h}$ time points as compared to 1 and $2 \mathrm{~h}$. In the blood of $40 \mathrm{mg} / \mathrm{kg}$ body weight treated mice, radioactivity significantly increased from 1 to $2 \mathrm{~h}$, decreased at $4 \mathrm{~h}$ time period and again increased significantly at $24 \mathrm{~h}$. The radioactivity in blood of mice treated with 20 and $40 \mathrm{mg} / \mathrm{kg}$ body weight significantly increased at $24 \mathrm{~h}$ compared to 1,2 and $4 \mathrm{~h}$. The radioactivity in spleen of mice treated with $20 \mathrm{mg} / \mathrm{kg}$ body weight significantly increased at $24 \mathrm{~h}$ time point compared to 1,2 and $4 \mathrm{~h}$. Dose-dependent distribution of NPs in lungs was significant at $24 \mathrm{~h}$ postinjection. The distribution of NPs to the blood and RES organs was initially low but increased slowly with time, suggesting potential distribution of radiolabeled NPs to these tissues. The increased radioactivity in blood at $24 \mathrm{~h}$ compared to the initial time points (1, 2 and $4 \mathrm{~h}$ ) suggests the progressive absorption of NPs into the blood following oral administration which may resulted in the increased distribution of NPs to the organs such as heart, lung, liver, spleen, muscle, bone and brain, as evident from the increased radioactivity in these organs at $24 \mathrm{~h}$ postinjection.

A remarkable difference was observed in the distributed concentrations of ${ }^{99 \mathrm{~m}}$ Tc-PEG-PLA NPs to the blood and organs of RES following i.v. and oral administration routes at all the time points tested. In addition, higher concentrations of NPs were observed in the heart, bone, intestine and brain of i.v. treated mice than orally treated mice at $24 \mathrm{~h}$ post-injection. The radioactivity in muscle and stomach was high in orally treated mice than the i.v. treated at $24 \mathrm{~h}$ post injection, which could be due to lower distribution of NPs to these tissues following i.v. injection.

\subsection{Gamma scintigraphy}

The distribution of PEG-PLA NPs to the organs of RES following i.v. injection in rat was validated by gamma imaging of whole animal. SPECT-CT images of rat following 4 and $24 \mathrm{~h}$ post-injection of ${ }^{99 \mathrm{~m}} \mathrm{Tc}-\mathrm{PEG}-\mathrm{PLA}$ NPs complex is shown in Figure 6(a) and 6(b). These images revealed the distribution of NPs to the organs of RES was high at $4 \mathrm{~h}$ and then gradually decreased at $24 \mathrm{~h}$ time point.

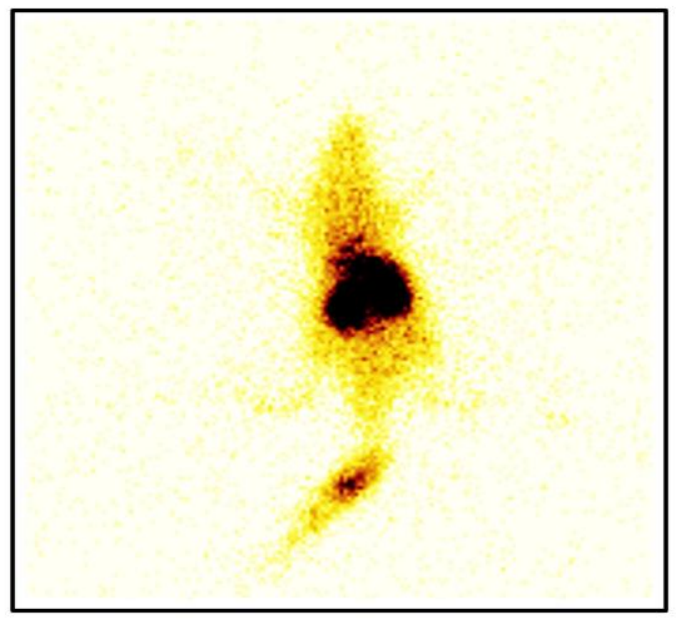

(a)

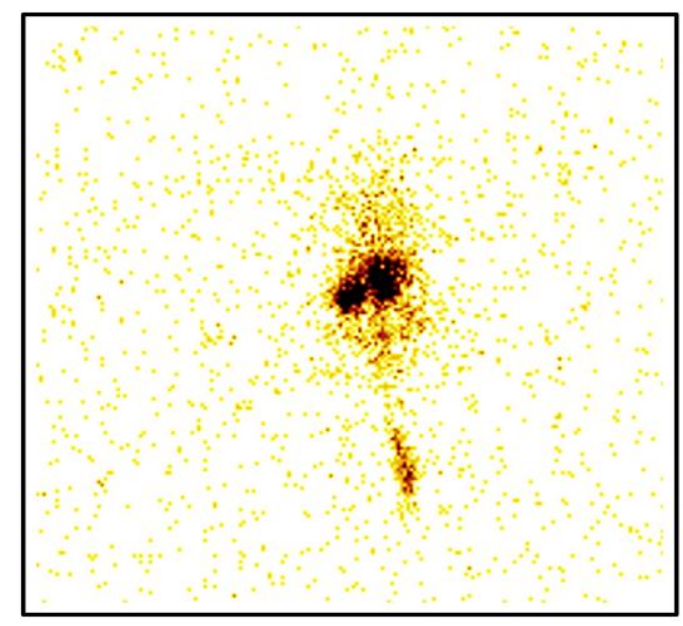

(b)

Figure 6. SPECT-CT images of i.v. injected ${ }^{99}$ Tc-PEG-PLA NPs complex into rat following $4 \mathrm{~h}$ (a) and $24 \mathrm{~h}(\mathrm{~b})$ post treatment. 


\subsection{Hematology and serum biochemistry}

Hematological parameters in blood of mice treated with PEG-PLA NPs through i.v. and oral routes, as determined by Automated Hematology Analyzer, are listed in Table 5(a). No significant change in the hematology parameters was observed in mice treated i.v. and orally with PEG-PLA NPs, which is consistent with the previous report by Harush-Frenkel et al., 2010. Biochemical parameters in the serum detected by autoanalyzer are listed in Table 5(b). No significant change in the serum levels of SGOT, bilirubin, urea and creatinine were observed in i.v. injected and orally administered mice compared to control and also between the two routes of administration. A significant increase in SGPT levels were observed in i.v. injected mice compared to control as well as orally treated groups. SGPT is found mainly in the liver. The interaction of NPs that are distributed to these organs at the cellular level could be responsible for the release of SGPT into the blood, which may have resulted in the increased SGPT levels observed in the present study.

Table 5.

(a) Hematological parameters of mice treated i.v. and oral with PEG-PLA NPS

\begin{tabular}{lccc}
\hline Name of the parameter & Control & PEG-PLA NPs i.v. & PEG-PLA NPs oral \\
\hline WBC $\left(x 10^{3} / \mu 1\right)$ & $4.56 \pm 0.17$ & $4.56 \pm 0.26$ & $4.96 \pm 0.12$ \\
RBC $\left(\times 10^{6} / \mu 1\right)$ & $8.81 \pm 0.17$ & $8.44 \pm 0.23$ & $8.41 \pm 0.27$ \\
Hgb $(\mathrm{g} / \mathrm{dL})$ & $13.5 \pm 0.26$ & $12.5 \pm 0.31$ & $12.5 \pm 0.32$ \\
HCT\% & $42.5 \pm 0.86$ & $41.1 \pm 1.16$ & $39.67 \pm 1.76$ \\
MCV (fL) & $48.0 \pm 1.73$ & $49.4 \pm 0.98$ & $50.4 \pm 2.75$ \\
MCH (pg) & $15.4 \pm 0.86$ & $12.9 \pm 0.34$ & $13.5 \pm 0.86$ \\
MCHC (g/dL) & $31.6 \pm 2.02$ & $27.3 \pm 0.85$ & $29.4 \pm 0.75$ \\
PLT $\left(x 10^{3} / \mu 1\right)$ & $740 \pm 23$ & $720 \pm 28.8$ & $717 \pm 28$ \\
LY\% & $71.1 \pm 4.61$ & $71.4 \pm 3.58$ & $69.4 \pm 3.38$ \\
GR\% & $28.2 \pm 4.04$ & $27.8 \pm 2.52$ & $30.9 \pm 3.37$ \\
RDW\% & $13.8 \pm 1.16$ & $14.9 \pm 1.67$ & $16.5 \pm 0.83$ \\
PCT\% & $0.27 \pm 0.01$ & $0.29 \pm 0.01$ & $0.28 \pm 0.02$ \\
MPV (fL) & $3.53 \pm 0.31$ & $3.73 \pm 0.29$ & $3.3 \pm 0.4$ \\
PDW\% & $20.4 \pm 1.44$ & $20.9 \pm 2.85$ & $20.4 \pm 1.34$ \\
\hline
\end{tabular}

(b) Serum biochemical parameters following i.v. and oral administration of PEG-PLA NPs in mice

\begin{tabular}{|c|c|c|c|c|}
\hline S. No. & Name of the parameter & Control & $\begin{array}{c}\text { Result } \\
\text { PEG-PLA NPs i.v. }\end{array}$ & PEG-PLA NPs oral \\
\hline 1 & SGOT (IU/L) & $83 \pm 4.04$ & $91 \pm 8.08$ & $94.6 \pm 3.18$ \\
\hline 2 & SGPT (IU/L) & $24.6 \pm 4.91$ & $62.6 \pm 4.33^{\mathrm{a}, \mathrm{b}}$ & $40.3 \pm 4.91$ \\
\hline 3 & Urea $(\mathrm{mg} / \mathrm{dL})$ & $53.3 \pm 3.75$ & $55.6 \pm 6.06$ & $55.6 \pm 6.06$ \\
\hline 4 & Creatinine (mg/dL) & $0.15 \pm 0.03$ & $0.24 \pm 0.02$ & $0.2 \pm 0.02$ \\
\hline 5 & Total bilirubin $(\mathrm{mg} / \mathrm{dL})$ & $0.35 \pm 0.02$ & $0.30 \pm 0.01$ & $0.25 \pm 0.04$ \\
\hline
\end{tabular}

${ }^{\mathrm{a} S i g n i f i c a n t}$ difference compared to control; ${ }^{\mathbf{b}}$ Significant difference between i.v. and oral treatments. $p<0.05$ was considered statistically significant in all the cases.

\subsection{Oxidative stress}

Oxidative stress markers such as GSH and LPO levels measured in liver, spleen, and kidney of mice treated i.v., and liver, stomach, and intestine of mice treated orally with PEG-PLA NPs is shown in Figures 7 and 8. A significant increase in GSH levels were observed in liver, spleen of mice injected i.v. shown in Figure 7(a) and liver, stomach, intestine of mice administered orally 
compared to control shown in Figure 7(b). LPO levels were slightly decreased in the liver, spleen, kidney of mice injected i.v. (Figure 8(a)) and stomach, intestine of mice administered orally compared to control. Significantly decreased LPO levels were observed in the liver of mice treated orally compared to control (Figure 8(b)). Following cellular internalization, PEGPLA NPs could be responsible for excess ROS generation results in oxidative stress (Zhao et al., $2008 \&$ Abbott et al., 2009). The enhanced GSH levels observed in the present study in response to the increased oxidative stress in liver, spleen of mice injected i.v. and liver, stomach, intestine of mice treated orally with PEG-PLA NPs could neutralize the effects of ROS and may potentially reduced the levels of LPO.

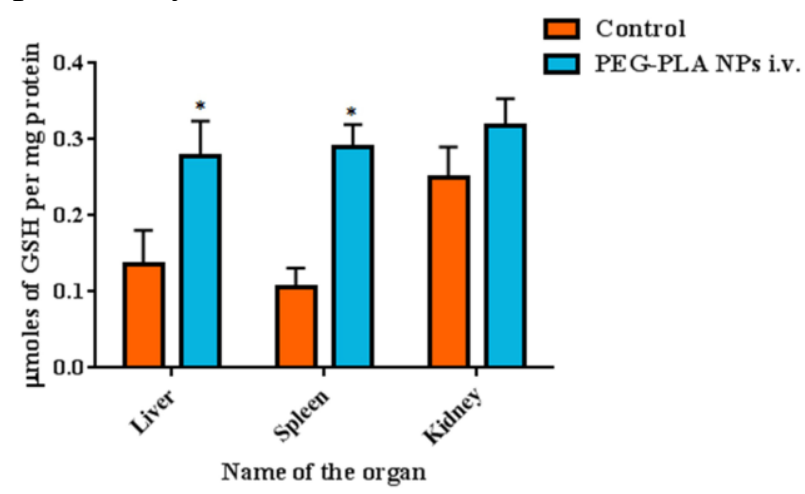

(a)

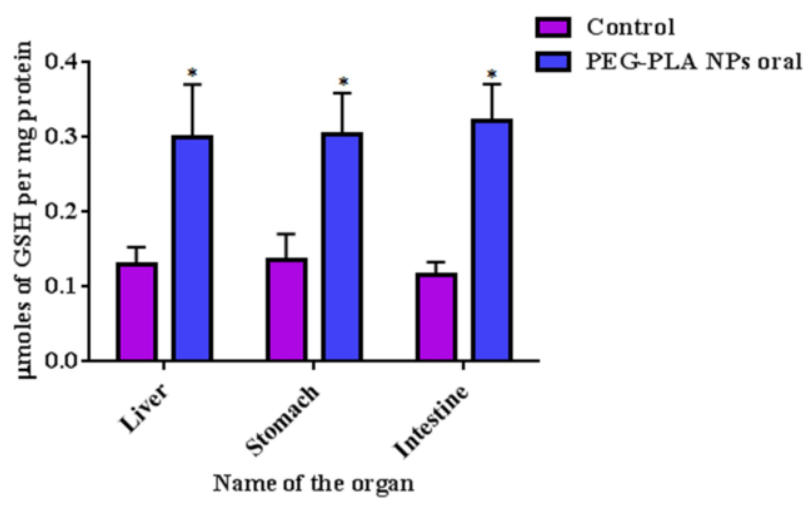

(b)

Figure 7. Graph shows the GSH Levels of (a) liver, spleen, kidney tissues of mice injected i.v. and (b) liver, stomach, intestine tissues of mice treated orally with PEG-PLA NPs. *Significant $(p<0.05)$ difference compared to control. i.v.- intravenous.

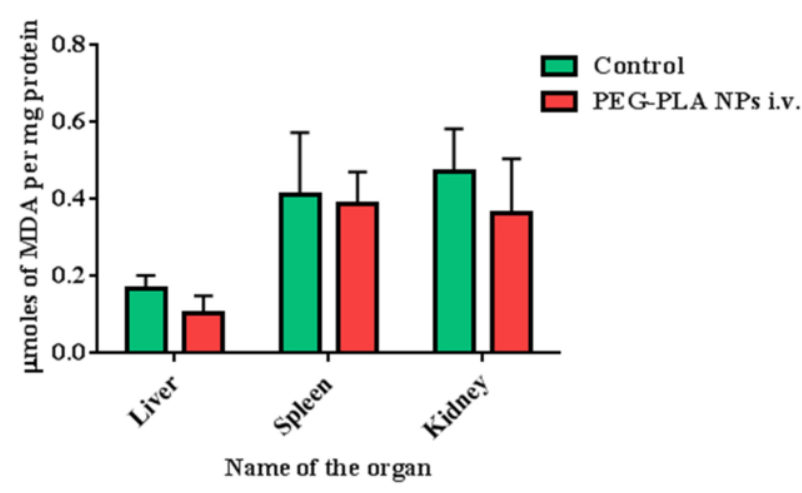

(a)

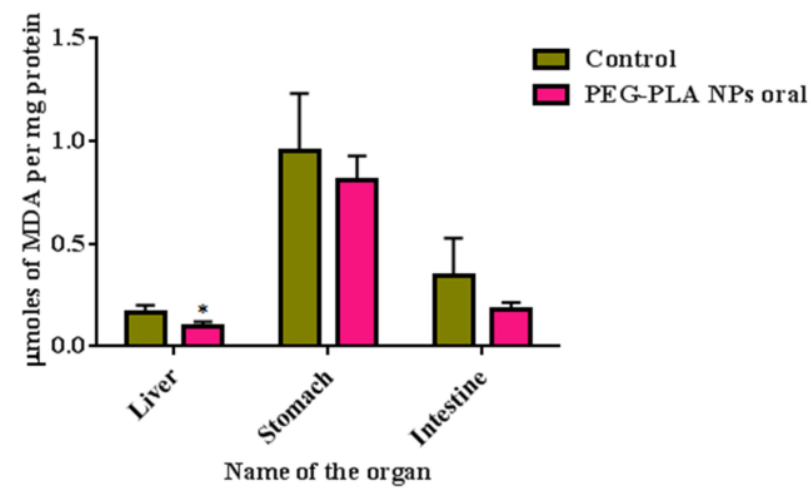

(b)

Figure 8. Graph indicates the LPO levels of (a) liver, spleen, kidney tissues of mice injected i.v. and (b) liver, stomach, intestine tissues of mice treated orally with PEG-PLA NPs. *Significant $(p<0.05)$ difference compared to control. i.v.- intravenous.

\subsection{Genotoxicity}

The genotoxic potential of PEG-PLA NPs treated through i.v. and oral routes was assessed by comet and MN formation assays. Results obtained from the evaluation of oxidative DNA damage in the liver, spleen, kidney cells of mice injected i.v. and the liver, stomach, intestine of mice administered orally by comet assay after exposure to PEG-PLA NPs is shown in Table 6(a) and 6(b). Cell viability for all the samples was found to be more than $90 \%$ in every experiment. A statistically significant DNA damage in liver, kidney of mice injected i.v. and stomach, 
intestine of mice administered orally was evident by an increase in comet parameters such as OTM and \% Tail DNA compared to control. Comet parameters in the liver of mice injected i.v. was higher $(p<0.01)$ compared to orally administered mice. DNA damage in the form of comets is shown in Figure 9(a) and 9(b).

Table 6.

(a) Comet parameters of liver, spleen, kidney tissues of mice treated i.v. with PEG-PLA NPS.

\begin{tabular}{lcccccc}
\hline $\begin{array}{c}\text { Name of the } \\
\text { sample }\end{array}$ & \multicolumn{2}{c}{ Olive tail moment } & (OTM) & \multicolumn{3}{c}{ \% Tail DNA } \\
Liver & Spleen & Kidney & Liver & Spleen & Kidney \\
\hline Control & $1.28 \pm 0.11$ & $2.34 \pm 0.08$ & $1.99 \pm 0.06$ & $11.68 \pm 1.3$ & $21.35 \pm 0.86$ & $22.51 \pm 1.07$ \\
PEG-PLA NPs i.v. & $3.36 \pm 0.14^{*}$ & $2.43 \pm 0.11$ & $4.01 \pm 0.13^{*}$ & $27.32 \pm 1.23 *$ & $23.78 \pm 1.19$ & $31.16 \pm 0.99^{*}$ \\
\hline
\end{tabular}

*Significant $(p<0.05)$ difference compared to control

(b) Comet parameters of liver, stomach, intestine tissues of mice treated orally with PEG-PLA NPS.

\begin{tabular}{llllllc}
\hline \multicolumn{1}{c}{$\begin{array}{c}\text { Name of the } \\
\text { sample }\end{array}$} & \multicolumn{2}{c}{ Oliver } & \multicolumn{1}{c}{ Stomach } & \multicolumn{1}{c}{ Intestine } & \multicolumn{3}{c}{ Liver } & \% Tail DNA \\
Stomach & Intestine \\
\hline Control & $1.28 \pm 0.11$ & $1.29 \pm 0.06$ & $1.70 \pm 0.07$ & $11.68 \pm 1.3$ & $13.68 \pm 0.93$ & $13.47 \pm 0.65$ \\
PEG-PLA NPs oral & $1.38 \pm 0.08$ & $2.09 \pm 0.12^{*}$ & $4.01 \pm 0.17^{*}$ & $13.52 \pm 1.08$ & $23.06 \pm 1.19^{*}$ & $28.5 \pm 1.17^{*}$ \\
\hline
\end{tabular}

* Significant $(p<0.05)$ difference compared to control

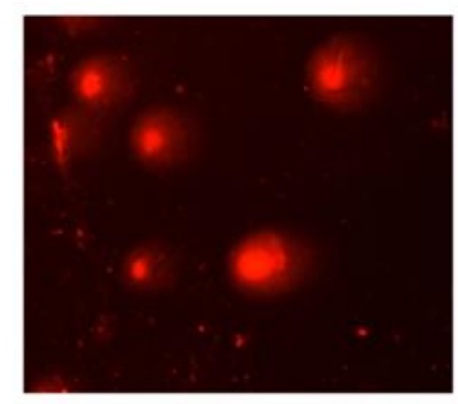

(a)

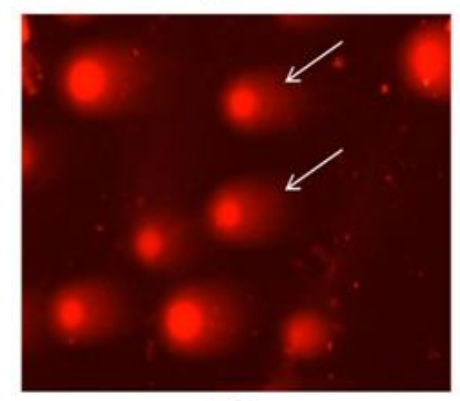

(a1)

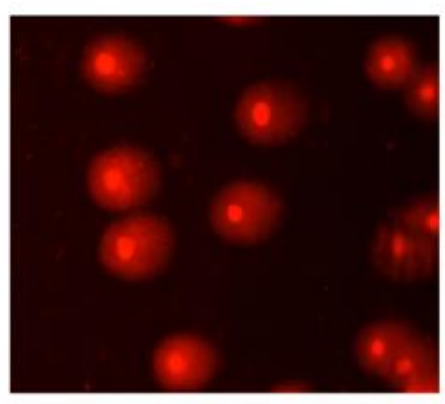

(b)

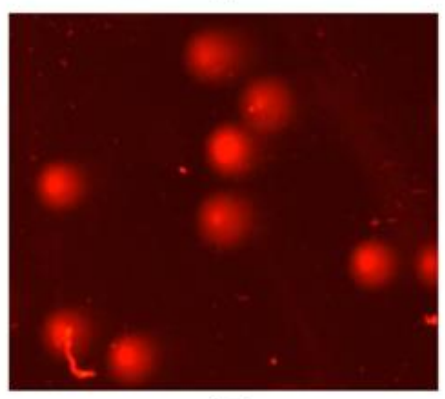

(b1)

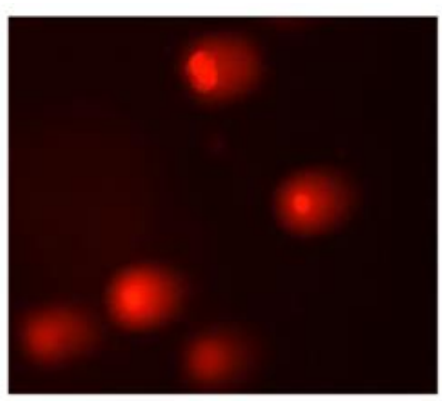

(c)

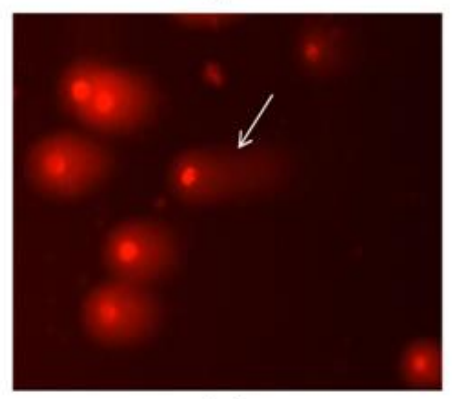

(c1)

Figure 9(a). Images (a), (b), (c) and (a1), (b1), (c1) showing the comet images of liver, spleen, kidney tissues of untreated mice and mice treated i.v. with PEG-PLA NPs. Arrows indicate the DNA damage in the form of comets 


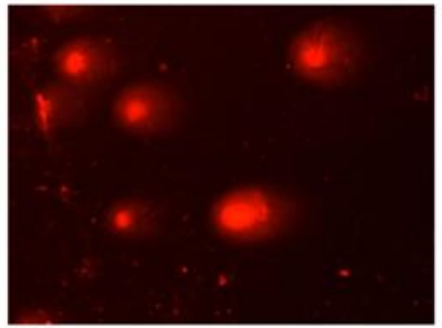

(d)

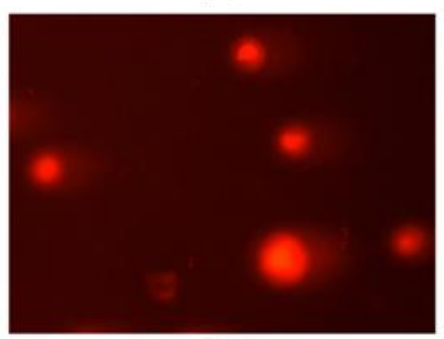

(d1)

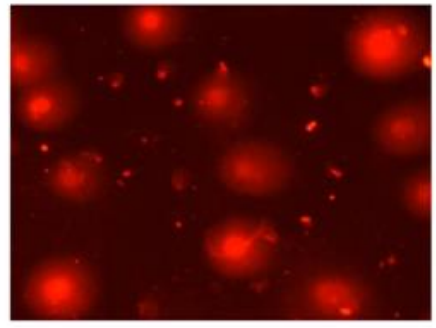

(e)

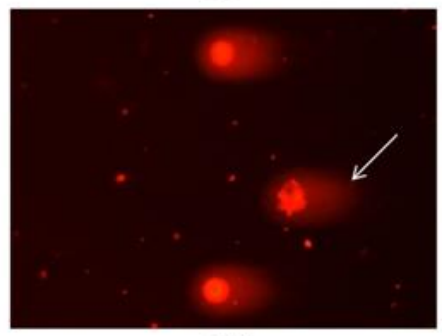

(e1)

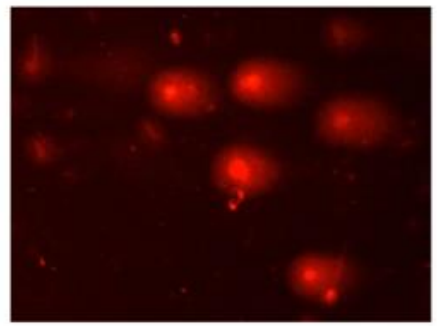

(f)

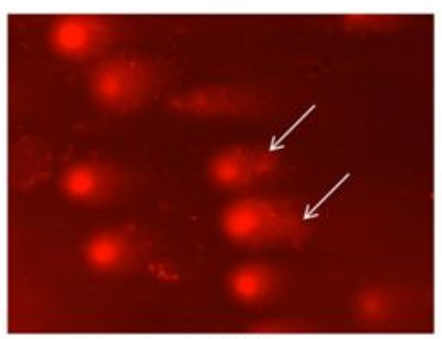

(f1)

Figure 9(b). Images (d), (e), (f) and (d1), (e1), (f1) showing the comet images of liver, stomach, intestine tissues of untreated mice and mice treated orally with PEG-PLA NPs. Arrows indicate the DNA damage in the form of comets

MN formation was significantly higher in liver, kidney tissues of mice injected i.v. (Table 7(a)) and intestine of mice treated orally (Table 7(b)) with PEG-PLA NPs compared to control.

Table 7.

(a) MN frequency of liver, spleen and kidney tissues of mice injected i.v. with PEG-PLA NPs.

\begin{tabular}{lllll}
\hline \multirow{2}{*}{ S. No. } & \multirow{2}{*}{ Name of the sample } & \multicolumn{3}{c}{ Micronuclei (\%) \pm SEM } \\
& & Liver & Spleen & Kidney \\
\hline 1 & Control & $0.7 \pm 0.2$ & $1.3 \pm 0.3$ & $1.7 \pm 0.7$ \\
2 & PEG-PLA NPs i.v. & $1.3 \pm 0.4^{*}$ & $1.9 \pm 0.7$ & $2.3 \pm 0.3^{*}$ \\
\hline
\end{tabular}

* Significant $(p<0.05)$ difference compared to control. i.v.- intravenous; SEM-standard error of mean

(b) MN frequency of liver, stomach and intestine tissues of mice treated orally with PEG-PLA NPS.

\begin{tabular}{llccc}
\hline \multirow{2}{*}{ S. No. } & \multirow{2}{*}{ Name of the sample } & \multicolumn{3}{c}{ Micronuclei (\%) \pm SEM } \\
& Liver & Stomach & Intestine \\
\hline 1 & Control & $0.7 \pm 0.2$ & $1.0 \pm 0.3$ & $0.9 \pm 0.4$ \\
2 & PEG-PLA NPs oral & $1.0 \pm 0.4$ & $1.3 \pm 0.7$ & $1.9 \pm 0.3^{*}$ \\
\hline
\end{tabular}

* Significant $(p<0.05)$ difference compared to control. SEM-standard error of mean

DNA damage observed in the tissues tested could be due to the induction of oxidative stress and also due to the direct interaction of NPs with the cellular DNA. Even though DNA damage was significant, as evident from genotoxic assays, the elevated GSH levels in response to increased ROS production may reduce the effects of ROS, thereby preventing further DNA damage.

\subsection{Histopathology}

The liver, spleen, kidney of mice injected i.v. and stomach, intestine of mice administered orally with PEG-PLA NPs showed no pathological changes and was also evident from the insignificant cell damage observed in the organs tested. Even though an increase in the SGPT 
levels and DNA damage were observed in mice treated i.v. with PEG-PLA NPs, there were no changes in the histology of the liver. The observation of unaltered histology of liver is supported by findings from a previous study (Zhang et al., 2007) nearly at the same dose (42.04 mg/kg body weight). The distribution of NPs to the lungs of mice treated i.v. with PEGPLA NPs caused moderate vascular congestion knows as "pulmonary vascular congestion" (PVC) as shown in Figure 10 (a) and 10 (b), which was consistent with a previous report by Li et al., 2014, who reported lung congestion in beagles injected with PEG-PLA micelles. Such preclinical assessments on the biodistribution and interaction of NPs with biological compartment such as cells and blood components could be helpful in understanding the in vivo fate of NPs intended for therapeutic applications.

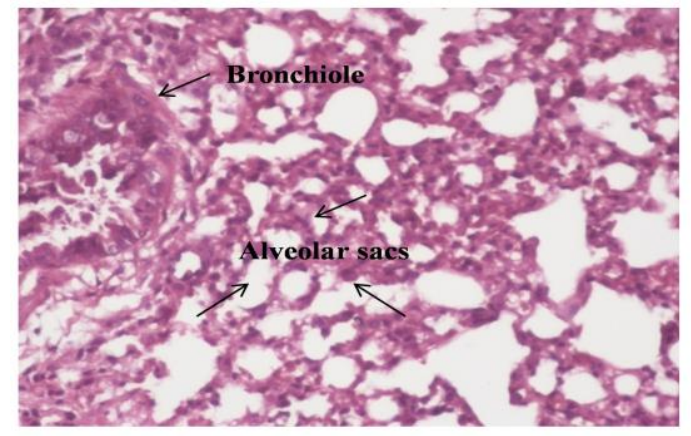

(a)

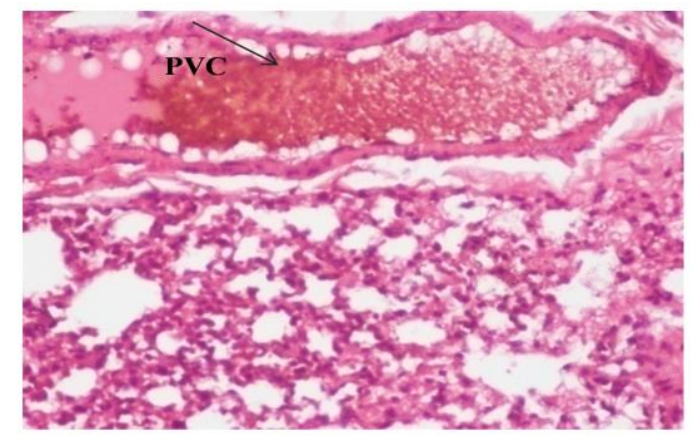

(b)

Figure 10. Histology mice lung (a) control and (b) treated i.v. with PEG-PLA NPs. PVC-pulmonary vascular congestion.

\section{Conclusion}

The present study illustrates the differences in biodistribution patterns following i.v. and oral routes of administration of two doses of PEG-PLA NPs. The higher concentration of radiolabeled NPs in blood compared to RES organs indicated the enhanced systemic circulation of these NPs following i.v. injection. Moreover, a dose-dependent distribution of NPs to the blood and RES organs following i.v. injection was observed. Furthermore, an increased distribution of NPs with time following oral administration to the organs such as the heart, lung, liver, spleen, muscle, bone and brain suggests their absorption after oral route. Such differences in the biodistribution profile following i.v. and oral administration routes could be due to the variations in the distributed concentrations of NPs to these organs. PEG-PLA NPs may thus consider as safe nanocarriers due to their hemocompatibility and potential to balance the oxidative stress. Even though PEG-PLA NPs induced DNA damage in the tested organs, no notable cell death was observed, indicating their compatibility at the tissue level. It is expected that an understanding of the biological interactions of the NPs, the consequences, and the associated mechanisms in vivo may considerably help in anticipating the safety of NPs. These investigations are expected to provide key information on the influence of administration route and dose on biodistribution profile and also on the resulting consequences of the nanoparticles' interaction with the biological components. A thorough understanding of the relationship between physicochemistry and pharmacokinetic profile of the carrier in preclinical models is essential to predict the efficacy and safety of the carrier, which would allow design of safer nanoparticles for targeted drug delivery systems suitable for human application. 


\section{Acknowledgements}

The authors are thankful to Sanofi R\&D, France for providing PEG-PLA copolymer. The authors are grateful to the Director, Institute of Nuclear Medicine and Allied Sciences (INMAS), Delhi for providing necessary facilities for radiolabeling experiments and biodistribution studies.

\section{References}

Abbott, D.A., Suir, E., Duong, G.H., de Hulster, E., Pronk, J.T., \& van Maris, A. J., (2009). Catalase overexpression reduces lactic acid-induced oxidative stress in Saccharomyces cerevisiae. Appl Environ Microbiol. 75: 2320-2325.

Afsharzadeh, M., Hashemi, M., Babaei, M., Abnous, K., \& Ramezani, M. (2020). PEG-PLA nanoparticles decorated with small-molecule PSMA ligand for targeted delivery of galbanic acid and docetaxel to prostate cancer cells. $J$ Cell Physiol. 235: 4618-4630. https://doi.org/10.1002/jcp.29339

Aula, S., Lakkireddy, S., Jamil, A., Kapley, A., Swamy, A.V.N., \& Reddy, L.H. (2015). Biophysical, biopharmaceutical and toxicological significance of biomedical nanoparticles. RSC Adv. 5: 47830-47859. https://doi.org/10.1039/C5RA05889A

Autio, K.A., Dreicer, R., Anderson, J., Garcia, J.A., Alva, A., Hart, L.L., Milowsky, M., Posadas, E.M., Ryan, C.J., Graf, R.P., Dittamore, R., Schreiber, N.A., Summa, J.M., Youssoufian, H., Morris, M.J., \& Scher, H.I. (2018). Safety and Efficacy of BIND-014, a Docetaxel Nanoparticle Targeting Prostate-Specific Membrane Antigen for Patients with Metastatic Castration-Resistant Prostate Cancer: A Phase 2 Clinical Trial. JAMA Oncol. 4:1344-1351.

Bazile, D., Prudhomme, C., Bassoullet, M.T., Marlard, M., Spenlehauer, G., \& Veillard, M. (1995). Stealth Me.PEG-PLA nanoparticles avoid uptake by the mononuclear phagocytes system. J Pharm Sci. 84: 493-498. https://doi.org/10.1002/jps.2600840420

Beutler, E., Duron, O., \& Kelly, B.M. (1963). Improved method for the determination of blood glutathione. J Lab Clin Med. 61: 882-888.

Countryman, P.I., \& Heddle, J.A. (1976). Production of micronuclei from chromosome aberrations in irradiated cultures of human lymphocytes. Mutat Res. 41: 321-332.

Ghasemi, R., Abdollahi, M., Emamgholi Zadeh, E., Khodabakhshi, K., Badeli, A., Bagheri, H., \& Hosseinkhani, S. (2019). Author Correction: mPEG-PLA and PLA-PEG-PLA nanoparticles as new carriers for delivery of recombinant human Growth Hormone (rhGH). Sci Rep. 9:12867.

Harush-Frenkel, O., Bivas-Benita, M., Nassar, T., Springer, C., Sherman, Y., Avital, A., Altschuler, Y., Borlak, J., \& Benita, S. (2010). A safety and tolerability study of differentlycharged nanoparticles for local pulmonary drug delivery. Toxicol Appl Pharmacol. 246: 8390. https://doi.org/10.1016/j.taap.2010.04.011.

Khaitan, D., Chandna, S., Arya, M.B., \& Dwarakanath, B.S. (2006). Differential mechanisms of radiosensitization by 2 -deoxy-D-glucose in the monolayers and multicellular spheroids of a human glioma cell line. Cancer Biol Ther. 5: 1142-1151.

Laughton, M.J., Halliwell, B., Evans, P.J., \& Hoult, J.R. (1989). Antioxidant and pro-oxidant actions of the plant phenolics quercetin, gossypol and myricetin. Effects on lipid peroxidation, 
hydroxyl radical generation and bleomycin-dependent damage to DNA. Biochem Pharmacol. 38: 2859-2865. https://doi.org/10.1016/0006-2952(89)90442-5

Le, T.C., Zhai, J., Chiu, W.H., Tran, P.A., \& Tran, N. (2019). Janus particles: recent advances in the biomedical applications. Int $J$ Nanomedicine. 14:6749-6777. https://doi.org/10.2147/IJN.S169030

Li, Y., Jin, M., Shao, S., Huang, W., Yang, F., Chen, W., Zhang, S., Xia, G., \& Gao, Z. (2014). Small-sized polymeric micelles incorporating docetaxel suppress distant metastases in the clinically-relevant 4T1 mouse breast cancer model. BMC Cancer. 14: 329.

Pourhojat, F., Shariati, S., Sohrabi, M., Mahdavi, H., \& Asadpour, L. (2018). Preparation of antibacterial electrospun Polylactic-co-glycolic acid nanofibers containing Hypericum Perforatum with bedsore healing property and evaluation of its drug release performance. Int. J. Nano Dimens. 9: 286-297.

Pridgen, E.M., Alexis, F., Kuo, T.T., Levy-Nissenbaum, E., Karnik, R., Blumberg, R. S., Langer, R., \& Farokhzad O. C. (2013). Transepithelial transport of Fc-targeted nanoparticles by the neonatal fc receptor for oral delivery. Sci Transl Med. 5: 213 ra167.

Raffaele Conte, R.., Calarco, A., \& Peluso, G. (2018). Nanosized biomaterials for regenerative medicine. Int. J. Nano Dimens. 9: 209-214.

Reddy, L.H., \& Bazile, D. (2014b). Drug delivery design for intravenous route with integrated physicochemistry, pharmacokinetics and pharmacodynamics: illustration with the case of taxane therapeutics. Adv Drug Deliv Rev. 71: 34-57. https://doi.org/10.1016/j.addr.2013.10.007

Reddy, L.H., Arias, J.L., Nicolas, J., \& Couvreur P. (2012). Magnetic nanoparticles: design and characterization, toxicity and biocompatibility, pharmaceutical and biomedical applications. Chem Rev. 112 :5818-5878.

Reddy, L.H., Sharma R.K., Chuttani, K., Mishra, A.K., \& Murthy, R.S. (2005). Influence of administration route on tumor uptake and biodistribution of etoposide loaded solid lipid nanoparticles in Dalton's lymphoma tumor bearing mice. J Control Release. 105: 185-198.

Richardson, V.J., Jeyasingh, K., Jewkes, R.F., Ryman, B.E., \& Tattersall, M.H. (1977). Properties of $[99 \mathrm{mTc}]$ technetium-labelled liposomes in normal and tumour-bearing rats. Biochem Soc Trans. 5: 290-291. https://doi.org/10.1042/bst0050290

Saini, P., Arora, M., Kumar, \& M.N.V.R. (2016). Poly (lactic acid) blends in biomedical applications. Adv Drug Deliv Rev. 107:47-59. https://doi.org/10.1016/j.addr.2016.06.014

Teleanu, R.I., Gherasim, O., Gherasim, T.G., Grumezescu, V., Grumezescu, A.M., \& Teleanu, D.M. (2019). Nanomaterial-Based Approaches for Neural Regeneration. Pharmaceutics. 11: E266. https://doi.org/10.3390/pharmaceutics11060266

Tice, R.R., Agurell, E., Anderson, D., Burlinson, B., Hartmann, A., Kobayashi, H., Miyamae, Y., Rojas, E., Ryu, J.C., \& Sasaki, Y.F. (2000). Single cell gel/comet assay: guidelines for in vitro and in vivo genetic toxicology testing. Environ Mol Mutagen. 35: 206-221.

Tobio, M., Sanchez, A., Vila, A., Soriano, I.I., Evora, C., Vila-Jato, J.L., \& Alonso, M.J. (2000). The role of PEG on the stability in digestive fluids and in vivo fate of PEG-PLA nanoparticles following oral administration. Colloids Surf B Biointerfaces. 18: 315-323. 
Verrecchia, T., Spenlehauer, G., Bazile, D.V., Murry-Brelier, A., Archimbaud, Y., \& Veillard, M. (1995). Non-stealth (poly (lactic acid-polyethylene glycol)) nanoparticles as injectable drug carriers. J controlled release. 36: 49-61. https://doi.org/10.1016/0168-3659(95)00053-B

Yu, D.H., Lu, Q., Xie, J., Fang, C., \& Chen, H.Z. (2010). Peptide-conjugated biodegradable nanoparticles as a carrier to target paclitaxel to tumor neovasculature. Biomaterials. 31: 22782292. https://doi.org/10.1016/j.biomaterials.2009.11.047

Zhang, Y., Hu, Z., Ye, M., Pan, Y., Chen, J., Luo, Y., Zhang, Y., He, L., \& Wang, J. (2007). Effect of poly (ethylene glycol)-block-polylactide nanoparticles on hepatic cells of mouse: low cytotoxicity, but efflux of the nanoparticles by ATP-binding cassette transporters. Eur J Pharm Biopharm. 66: 268-280. https://doi.org/10.1016/j.ejpb.2006.11.003

Zhao, L., He, J., Wang, X., \& Zhang L. (2008). Nitric oxide protects against polyethylene glycolinduced oxidative damage in two ecotypes of reed suspension cultures. J Plant Physiol. 165: 182-191. https://doi.org/10.1016/j.jplph.2007.03.002 